\title{
SMEs' Growth Heterogeneity - Evidence from Regional Developments
}

\author{
Christina E. Bannier ${ }^{1} \&$ Sabrina Zahn ${ }^{2}$ \\ ${ }^{1}$ Corporate Finance, Gutenberg-University Mainz, Mainz, Germany \\ ${ }^{2}$ Frankfurt School of Finance \& Management, Germany \\ Correspondence: Christina E. Bannier, Professor of Corporate Finance, Gutenberg-University Mainz, \\ Jakob-Welder-Weg 9, 55128 Mainz, Germany. Tel: 49-6131-392-2979. E-mail: bannier@uni-mainz.de \\ Received: January 16, 2014 \\ Accepted: February 12, 2014 \\ Online Published: March 1, 2014 \\ doi:10.5430/ijba.v5n2p23 \\ URL: http://dx.doi.org/10.5430/ijba.v5n2p23
}

\begin{abstract}
Previous empirical research on small and medium-sized enterprises (SMEs) frequently struggled with the extreme heterogeneity of these frms. We scrutinise one major source of this heterogeneity: SMEs' growth development. Based on a large dataset of French, Italian, UK and US firms between 2000 and 2008, we find that SMEs fall in two categories in all countries: One large group of firms that display only slow growth and one much smaller group that actively seek strong growth. We show that the growth factors particularly of the slowly-growing firms vary strongly between the countries. European SMEs differ mainly in the growth effects of their ownership structures. US firms set themselves apart via the growth impact of their capital structures. Strongly-growing SMEs, in contrast, develop much more homogeneously in cross-country comparison.
\end{abstract}

Keywords: small and medium-sized enterprises, SMEs, growth analysis, system-GMM estimation

\section{Introduction}

In many countries, small and medium-sized enterprises (SMEs) are the backbone of the economy. Due to increased data availability a large number of studies have focused on the particular role that SMEs play. However, the simple classiffication according to size that distinguishes between large firms on the one hand and SMEs on the other falls short of a full characterisation of these firms. SMEs have rather been found to be extremely heterogeneous in many respects (Hurst and Pugsley, 2011). Failure to account for this heterogeneity may lead to inaccurate conclusions for the 'average' SME. This paper attempts to address this lack of accuracy. We analyse SMEs' heterogeneity with regard to one particular aspect that is at the heart of their classiffication: the growth process. We examine whether SMEs differ in their growth development and try to single out the respective growth determinants.

The number of studies that scrutinise the growth behavior of small and mediumsized firms is still relatively small. Business cycle analyses have shown thatfirm growth varies over the business cycle and that SMEs and large firms grow differently. Whereas large firms appear to expand faster during recessions and recoveries, small firms have been found to prosper particularly during booms (Hardwick and Adams, 2002; Higson et al., 2002; 2004). Undoubtedly, access to capital is key to fuel growth (Becchetti and Trovato, 2002). Many empirical studies have therefore tested capital structure theories with mixed results for SMEs. Huynh and Petrunia (2010) demonstrate that strongly growing firms show higher debt levels than firms with lower growth. Their research implies that external finance is crucial for growth. In contrast, Timmons (1994) shows that small and young firms tend to draw capital from internal sources and rely on external capital only in later stages of their development. Similarly, Elston (2002) reports that cash flow positively affects firm growth and that those SMEs with more and stronger investment opportunities possess a larger proportion of liquidity (Note 1).

However, recent studies have also argued that SMEs pursue stability rather than growth and therefore choose different capital structures than what theories, based on the assumption offirms pursing a steep growth path, proclaim (Walker and Brown, 2004; Vos and Roulston, 2008). In this respect, Bannier and Zahn (2012) find that SMEs are not simply 'little large firms', but show completely different growth characteristics. They argue that the simple distinction of firms according to size falls short of a full assessment that should comprise ownership type and structure as well as liability aspects. Overall, these studies conclude that SMEs rarely intend to grow strongly: "[...] We find that most small businesses have no desire to grow big or to innovate in any observable way. [...] We show non pecuniary benefits (being one's own boss, having flexibility of hours, etc.) play a first-order role in the business formation 
decision." (Hurst and Pugsley, 2011).

Corroborating the altogether mixed findings regarding the drivers of SMEs' growth behavior, recent studies show that a subgroup of firms indeed targets strong expansions (Moreno and Casillas, 2007). As a consequence, neglecting the large degree of heterogeneity among SMEs may significantly impair the conclusions of any study that contains SME data: Since large firms must start small as well, it may be the case that empirical analyses unwittingly capture two different groups of firms - the slowly-growing SMEs that remain within their size definition for a long time on the one hand and the stronglygrowing firms that aim to outgrow the SME size definition and become large quickly on the other. The only way to circumvent false conclusions from SME data would be to make sure that the SME size definition holds for every year over a large sampling period. However, only few studies do this.

Most analyses require the SME definition to hold only for the starting year of the sample (Carpenter and Petersen, 2002; Mateev and Anastasov, 2010). Since there is a high risk that the so-collected group of SMEs contains the not-yet large firms as well that follow completely different aims and have completely different characteristics than the average SME, it is important to examine how significant the resulting bias may be. This is exactly what our paper does. Moreover, we analyse in how far the growth determinants of the strongly-growing firms differ from those of the more stable firms. Since there are indications that growth determinants may be strongly country-dependent (Biosca, 2010; Beck et al., 2005; Costantini, 2008; Rajan and Zingales, 1998), we consider firms from two continental European countries (France and Italy), the UK and the US and run separate analyses for each country and respective group of SMEs.

Our study is based on a large dataset that covers French, Italian, UK and US firms between 2000 and 2008. Using data from the AMADEUS and ORBIS databases of BUREAU VAN DIJK Electronic Publishing GmbH, we select those firms that qualify as small and medium-sized in all years (hereinafter also referred to as 'stable SMEs' or 'STs'). (Note 2) Additionally, we select a second group of firms that comply with the SME definition in the first year, i.e. in 2000, but outgrow the size definition for at least the last two years of the sample, i.e. 2007 and 2008 (hereinafter also referred to as 'growing SMEs' or 'GRs'). In this sub-sample, firms outgrow the SME size definition on average after four years. To contrast the growth processes of these two groups of firms, we employ a system-GMM dynamic panel estimation procedure based on Arellano and Bover (1995) and Blundell and Bond (1998). This allows to assess causal relationships between growth drivers and growth outcome.

We find that weakly-growing SMEs indeed display different growth patterns as compared to strongly-growing SMEs. Especially for stable SMEs, we furthermore observe country-dependent growth drivers. While all GRs make strong use of their internal means to finance their growth paths and use additional debt financing, this is not the case for the STs. For the slowly-growing SMEs we rather find diverging growth effects of their ownership and capital structures in a cross-country comparison. More precisely, we observe that while French and UK SMEs seem to benefit from family holdings, Italian firms suffer in their growth processes if they are controlled by a family. UK firms, in contrast, appear to be negatively affected by employee ownership holdings. Finally, US firms are the only ones to strive for high levels of equity capital in order to support their growth processes.

Overall, we contribute to the literature in three ways: first, we emphasise the determinants of firm growth within the framework of an 'human and other resources approach' a la Penrose (1959), second, we provide further empirical evidence of SMEs' heterogeneity, and explain, third, in which way firm growth patterns diverge in different countries.

The rest of the paper proceeds as follows. Section 2 briefly reviews the literature and describes the growth factors to be considered in the analysis. Section 3 delineates the model specification and presents the empirical estimation methodology. Section 4 describes the data set. Results are presented and discussed in Section 5 and Section 6 concludes.

\section{Literature Review and Derivation of Hypotheses}

In one of the latest attempts to classify the growth literature into coherent streams, McKelvie and Wiklund (2010) differentiate between the following three strands: 1) growth as an outcome, 2) the outcome of growth and 3) the growth process. The first strand employs growth as dependent variable and explores growth determinants. The second strand, in contrast, uses growth as an exogenous variable and explains changes within the organisation resulting from growth. The third strand finally deals with the growth process itself which is treated as a 'black box' in the other strands. Section 2.1 derives our our main research focus based on the first and third strands of the literature. Section 2.2 discusses relevant growth determinants that we will employ in our growth as an outcome model. 


\subsection{Growth Patterns of SMEs}

Particularly the third strand of the growth literature (growth process) provides tentative evidence that SMEs indeed display distinct growth characteristics. Churchill and Lewis (1983), for instance, develop a framework of a five-stages growth model based on a literature review, expert knowledge and questionnaire data. According to their model, firms that overcome the first two stages of 'existence' and 'survival' need to decide at the third 'success' stage, whether they want to expand further or maintain their status quo. Furthermore, Witt (2000) shows how entrepreneurs' dynamism is gradually replaced with a more bureaucratic structure as growth requires an expansion of the firms' organisation. He demonstrates that the development of firms branches off in diverse directions when the firm size has reached a stage where the organisation needs to be expanded in order to continue the growth path. Birley and Westhead (1990) perform a comprehensive econometric analysis to provide empirical evidence on the 'stages of growth theories'. However, they fail to find evidence that (all) firms pass through a generalised series of respective growth stages as not every newly founded firm survives and/or also grows into a large firm.

The literature has also highlighted the reasons of surviving firms not to focus on further growth. Wiklund et al. (2003), for example, analyse the motivation of small business managers to expand their firms. They find that the financial results of growth may not be as important as noneconomic concerns like the loss of a positive working atmosphere to the managers. Furthermore, according to Gimeno et al. (1997), the survival of a firm is influenced not only by its economic performance, but also by a firm-specific performance threshold that must not be undercut in order for the dominant organisational constituent to not break up the business. The authors highlight the strong positive psychological benefits from entrepreneurship that can lower the performance threshold level and therefore reduce the necessary economic returns. Gimeno et al. (1997) therefore provide an explanation for the persistence of underperforming but nevertheless surviving firms.

That firm growth is generally not the primary motivation of small business owners is also underlined by studies on the capital structures of SMEs. Vos et al. (2007) and Vos and Roulston (2008) refer to the fact that SMEs often do not seek funding to induce growth as 'financial contentment'. Overall, these studies conclude that a majority of SMEs pursue stability rather than growth and therefore choose different capital structures than what traditional theories, based on the assumption of growth, would proclaim (Walker and Brown, 2004; Vos and Roulston, 2008). Muller (2008) furthermore examines the interplay of benefits of control, the capital structure and firm growth. On the basis of a data set of private UK firms that covers a large number of SMEs, she shows that a business owner's fear of losing control during an expansion leads to smaller increases in equity, higher leverage ratios and slower firm growth.

Most closely related to our work is the paper by Moreno and Casillas (2007). They show in a discriminant analysis that high-growth SMEs indeed coexist with non-highgrowth SMEs. We augment their analysis by studying the growth factors of the two types of firms in detail. We furthermore examine the growth determinants in an international context to see whether regional differences show up in the split between strongly growing and weakly growing SMEs. Essentially, we aim to contribute to a more precise assessment of SME heterogeneity and, hence, to remedy one of the basic pitfalls of any empirical study on SMEs: Since both high-growth and stable SMEs are, by definition, lumped together as SMEs at the beginning of any observation period, conclusions are drawn from the average SME. This clearly does not do justice to either type of firm. If the observation period were sufficiently long, the first sub-group would eventually be identified as large firms. Given the still comparably scarce availability of historical data on SMEs, however, there is a high risk that the observation period is not long enough, respectively the control for compliance with the size definition is not strict enough so that strongly biased results may be derived. In this paper, we try to tackle this bias.

\subsection{Determinants of Firm Growth}

In order to test for the growth heterogeneity of SMEs and its causes, we develop a firm growth model and employ a number of growth determinants in accordance with the literature. Similar to Bannier and Zahn (2012), our growth analysis differentiates between growth factors that are (i) inherent in thefirm, and as such in the growth process, (ii) endogenous in that the company chooses them actively in order to influence the growth process, or (iii) exogenous to the firm and as such cannot be altered or avoided. Accordingly, we conjecture that firms planning to outgrow the SME status quickly will more actively use the endogenous growth factors than the more stable SMEs.

Among the firm-inherent growth factors, we consider firm age and size. With regard to firm age, many studies support a negative relationship between growth and age both for large firms (Evans, 1987; Hall, 1987, Dunne and Hughes, 1994; Bottazzi and Secchi, 2003) and for SMEs (Das, 1995; Harhoff et al., 1998; Huynh and Petrunia, 2010). The impact of age may also depend on the applied size measure: Heshmati (2001), for instance, derives a 
negative relationship between firm age and employment growth, but detects a positive impact of age on asset and sales growth.

According to Gibrat's (1931) 'Law of Proportionate Effect', firm growth rates are independent of firm size. While some studies concur with Gibrat's law (especially the early studies, e.g. Hart and Prais, 1956; Simon and Bonini, 1958), others refuse it (therefore confirming that smaller firms grow faster than larger firms as displayed by e.g. Kumar, 1985; Evans, 1987; Dunne and Hughes, 1994; Bottazzi and Secchi, 2003; Moreno and Casillas, 2007) (Note 3). Analyses of the size effect on firm growth furthermore succumb to the problem of serial correlation as growth is typically measured as the change in a firm's size. While this poses econometric problems, even the direction of the serial correlation effect is unclear (Note 4). Coad (2007a) concludes that smaller firms are more prone to experience negative autocorrelation in contrast to larger firms that seem to have a tendency towards positive autocorrelation.

Another inherent growth factor that is often applied as control factor in crosssectional studies on firm growth is the industry affiliation of firms. Audretsch et al. (1998) show that stylized facts regarding links between firm growth, survival, size, and age, which have been primarily derived from studies focusing on manufacturing firms, are different from those for services firms. Their results suggest that services firms differ particularly with respect to their negligible economies of scale. Moreno and Casillas (2007) derive the distinction between high-growth and non-high-growth SMEs by measuring firm growth relative to the average growth of the respective industry and, hence, corroborate the importance of industry considerations.

As regards endogenous growth factors, a plethora of different variables has been examined. What appear to be the most important growth drivers in this respect are firms' choices with respect to their ownership and, thus, corporate governance structure, and their capital structure including their use of earnings. A stock listing may easily be expected to induce positive growth effects as the company has an incentive to satisfy the new shareholders' demand for expected returns. Accordingly, Arthurs and Busenitz (2006) or Florin (2005) detect positive growth effects for listed firms. Family shareholders, in contrast, may be assumed to focus on multiple aims rather than solely on pure firm growth. Hamelin and Trojman (2007), for example, show for a sample of French SMEs that firms' sales growth is lower the stronger the family control is. It may therefore be expected that the shareholding of families/individuals hinders firm growth. However, Chu (2009) reports for a sample of listed Taiwanese SMEs that companies with strong family ownership display higher growth. Sesil et al. (2007) furthermore finds that US firms with broad-based stock option plans display higher levels of firm growth (measured as sales and employment growth) compared to similar firms without such employee incentive plans. Hence, employee ownership participation may be expected to spur positive growth effects.

Capital structure theories traditionally have strong ties to models of firm growth. According to the pecking order theory (Myers and Majluf, 1984), a firm's availability of internal liquidity is a key prerequisite for the realisation of early growth opportunities (Almeida et al., 2004; Faulkender and Petersen, 2006; Pal and Ferrando, 2010). However, external debt capital may help to overcome agency problems that can lead to too low growth (Jensen, 1986). Nevertheless, the juncture of growth studies and capital structure analyses has primarily focused on sufficient capital as a prerequisite for growth, the so-called financing constraints literature (Carpenter and Petersen, 2002). Angelini and Generale (2008), for example, confirm that financial constraints affect firm growth negatively where SMEs (i.e. especially younger and smaller firms) are more strongly affected than larger firms. In the same vein, Wagenvoort (2003) shows for European SMEs that the growth sensitivity to cash flow rises as firm size falls.

Eventually, firm growth will be spurred by using profits in order to invest in growth opportunities. With regard to this most basic endogenous growth factor, it has been shown that growth rates rise along with profitability as firms retain their earnings (Downie, 1958). Moreover, Elston (2002) reports that cash flows affect firm growth positively.

Finally, with regard to exogenous growth factors, the macroeconomic environment appears to be particularly relevant. Very often, it has been found that the economic climate affects firm growth (Beck et al., 2005; Higson et al., 2002 ; 2004) and that differences between firms of different sizes are visible (as displayed for UK life insurance firms by Hardwick and Adams, 2002). Hardwick and Adams (2002) find that SMEs prosper particularly during booms, whereas larger firms appear to expand faster during recessions and recoveries.

In this paper, we build a growth as outcome model and analyse the effects of the respective growth determinants separately for the two groups of SMEs (stable and stronglygrowing SMEs). We hypothesise that SMEs that decide to grow strongly rely mainly on growth factors that they can actively influence i.e. endogenous growth determinants. Accordingly, we expect to find differences between the two groups of SMEs particularly with regard to the growth effects of ownership structures, capital structures and the employment of earnings. 


\section{Model Specification and Estimation Method}

Our empirical testing procedure analyses the growth development of all firms that have been classiffied as SMEs at the beginning of our sampling period. We then subdivide this total sample into those SMEs that remain small throughout the time period and those that outgrow the size definition and become large. Our analysis takes all of the aforementioned growth factors into account. In order to test our hypotheses, we run separate regressions on the two groups of SMEs for each country. By comparing the growth sensitivities, i.e. the growth factors' coefficients - both with respect to statistical and economic significance and sign - we hope to be able to see whether the two groups of SMEs indeed behave differently. We are particularly interested in analysing whether the strongly-growing SMEs make stronger use of endogenous factors to foster growth. Additionally, we test whether there are cross-country differences in the employment of growth factors within the two groups of SMEs.

The following variables will be employed in our analyses. Following Penrose (1959), firm growth $(\triangle \operatorname{LogSIZE})$ as the dependent variable is measured based on two different size variables: Total assets and the number of employees. Each one-year growth measure is derived by taking log-differences of the respective current and last year's size variables, which is the most common way of measuring proportional growth. Using log-differences instead of simple differences has the advantage that econometric results are less affected by heteroscedasticity (Coad and Holzl, 2010). With regard to the explanatory variables of the firm growth regression, we follow Cooley and Quadrini (2001) and Huynh and Petrunia (2010) and employ the lagged firm size measure (L.LogSIZE) as a first regressor in order to capture productivity differences of firms. Firm age is included as an additional inherent growth factor, both in logarithmic form $(\log A G E)$ and as the squared logarithm $(\log A G E 2)$ to control for a non-monotonic impact of firm age on firm growth.

To describe the ownership and, hence, also the corporate governance structure of firms, we use the following four variables. Similar to Mateev and Anastasov (2010), we apply a dummy variable for the listing status of the firms: PUBLIC takes a value of 1 if the firm is publicly listed and 0 otherwise. We furthermore control for the number of shareholders $(N U M B S H)$ as well as for different types of shareholders: TYPSHIF is a dummy variable that takes a value of 1 if individuals/families are firm owners and 0 otherwise, TYPSHEM is a respective dummy for employee ownership. Unfortunately, all governance variables of our data sample are only available for the last year of our sampling period so that no changes within the observation period can be analysed. The interpretation of governance effects is therefore limited and only valid under the assumption that no major changes in the governance structure have taken place within the observation period. This is clearly a limitation and we will, accordingly, interpret the results with caution.

The capital structure is captured by the equity ratio $(E R)$. Among the performancerelated variables, we consider the logarithm of total sales (LogSALES) as a proxy for internally generated financial means and firm profitability $(P R O F) . P R O F$ is defined as net income divided by total sales.

In order to capture the exogenous effect of the economic climate, we include both the current level of the respective national $G D P$ as well as the lagged level of GDP $(L . G D P)$ of the particular country. We alternatively employ the growth rate of the respective national GDP as explanatory variable (GDPGR).

Furthermore, we control for industry effects (Note 5) and employ time-dummies to prevent cross-individual contemporaneous correlation (Roodman, 2009). The canonical specification of our firm growth model is hence given as follows:

$$
\begin{aligned}
& \triangle \operatorname{LogSIZE} E_{i t}=\alpha_{i}+\beta_{1} \operatorname{L} \operatorname{LogSIZ} E_{i t}+\beta_{2} \log A G E_{i t}+\beta_{3} \log A G E 2_{i t} \\
& +\gamma_{1} \text { Govit }_{i t}+\gamma_{2} E_{\text {Rit }}+\gamma_{3} \operatorname{LogSALES} \text { it }+\gamma_{4} \text { PROF }_{i t} \\
& +\delta_{1} G D P_{t}+\delta_{2} L \cdot G D P_{t}+\varepsilon_{i t}
\end{aligned}
$$

Here, Gov is a vector of ownership and corporate governance regressors including the public dummy, the number of shareholders and the two types of shareholder dummy variables.

The dynamic firm growth equation specified above requires the employment of dynamic panel data methods like the difference-GMM or system-GMM estimation procedures. The system-GMM estimation method is usually more effcient for small-T, large-N panels than the difference-GMM estimation by Arellano and Bond (1991). We follow Huynh and Petrunia (2010) and Coad (2007b) who employ the system-GMM dynamic panel data estimator based on Arellano and Bover (1995) and Blundell and Bond (1998) in order to analyse firm growth. A major advantage of the system-GMM estimation procedure is that this method is able to deal with reverse causality in a model with only a 
limited set of explanatory variables. Furthermore, this method provides consistent estimates and avoids biases from unobserved heterogeneity (Huynh and Petrunia, 2010).

We control for second and third order serial correlation and include additional lags of the size variable as regressors (similar to Chesher, 1979) in order to guarantee that the estimates are still consistent. This is important because second order autocorrelation implies that the second lag level of the independent variable is no longer exogenous.

Therefore, our firm growth equation eventually becomes:

$$
\begin{aligned}
& \Delta \operatorname{LogSIZ} E_{i t}=\alpha_{i}+\beta_{1} L \cdot \operatorname{LogSIZ} E_{i t}+\beta_{2} L 2 \cdot \operatorname{LogSIZ} E_{i t}+\beta_{3} L 3 \cdot \operatorname{LogSIZ} E_{i t} \\
& +\beta_{4} \log A G E_{i t}+\beta_{5} \log A G E 2_{i t} \\
& +\gamma_{1} \text { Gov }_{i t}+\gamma_{2} \text { ER }_{i t}+\gamma_{3} \operatorname{LogSALES} S_{i t}+\gamma_{4} \text { PROF }_{i t} \\
& +\delta_{1} G D P_{t}+\delta_{2} L \cdot G D P_{t}+\varepsilon_{i t}
\end{aligned}
$$

As a consequence of the inclusion of the additionally lagged size variable, we perform the Arellano-Bond tests to control for serial correlation up to order 4. The system-GMM estimation allows to employ the lagged levels and lagged differences of the respective endogenous variables as instruments. Therefore, the system-GMM estimation procedure effectively deals with any inconsistencies arising from a potential simultaneity bias. We treat the lagged size variables (L.LogSIZE, L2.LogSIZE and L3.LogSIZE), the equity ratio (ER) and the performance-related measures (LogSALES and PROF) as endogenous variables. We furthermore report tests on the validity of the applied instruments. Since non-sphericity may be suspected to affect the error terms, (Note 6) the Sargan statistic is inconsistent (Roodman, 2009).

\section{Data Description and Univariate Analysis}

Our dataset is based on the AMADEUS and ORBIS databases, offered by BUREAU VAN DIJK Electronic Publishing GmbH for the years 2000 to 2008 . We apply the definition of small and medium-sized firms (SMEs) by the Statistics of U.S. Business that defines SMEs as firms with less than 500 employees. Additionally, we require total sales to be below 50 million Euros per year (Note 7). We therefore select those firms into the SME sample that classify as SME in all years of the observation period. Additionally, we select a second group of firms that comply with the SME definition in the first year, i.e. in 2000, but outgrow the size definition for at least the last two years of the observation period, i.e. 2007 and 2008. The first group of firms is referred to as 'stable SMEs' (STs) and the second group of firms is referred to as 'growing SMEs' (GRs) in the following.

We perform a thorough data cleaning procedure and delete obviously faulty data entries. After this, we are left with 26,646 STs and 1,491 GRs. As can be seen from Table 1, both in the French, Italian and UK sample, STs make up more than $90 \%$ of all observations. The US sample, in contrast, comprises a much larger share of GRs (24.3\%) than the European samples. For each of these firms we collect general information such as the founding year, legal status, number of employees, industry etc. as well as balance sheet and profit and loss data.

Table 1. Overview data sample

\begin{tabular}{lrrrrrrrrrr}
\hline & \multicolumn{1}{c}{ France } & \multicolumn{2}{c}{ Italy } & \multicolumn{2}{c}{ UK } & \multicolumn{3}{c}{ US } & \multicolumn{3}{c}{ Total } \\
\hline & $\#$ & $\%$ & $\#$ & $\%$ & $\#$ & $\%$ & $\#$ & $\%$ & $\#$ & $\%$ \\
\hline STs & 3,346 & 97.8 & 16,080 & 95.4 & 6,949 & 92.6 & 271 & 75.7 & 26,646 & 94.7 \\
GRs & 74 & 2.2 & 773 & 4.6 & 557 & 7.4 & 87 & 24.3 & 1,491 & 5.3 \\
\hline Total & 3,420 & 100.0 & 16,853 & 100.0 & 7,506 & 100.0 & 358 & 100.0 & 28,137 & 100.0 \\
\hline
\end{tabular}

In the following, Tables 2, 3 and 4 list descriptive statistics of our data sample. As should have been expected, Table 2 shows much higher growth rates (measured either as one year growth rate in total assets, TAGR, or total employment, TEGR) for the GRs in contrast to the STs in all country samples. The differences in means are highly significant as reported by the p-values in the last column of the Tables. The development of the growth rates and the business cycle per country over the sampling period is also displayed in Figure 1. Simple visual inspection shows how different the firms in the four countries react to changes in the surrounding economy. Particularly US firms' growth rates seem to be strongly affected by the GDP development. 


\section{France Italy}

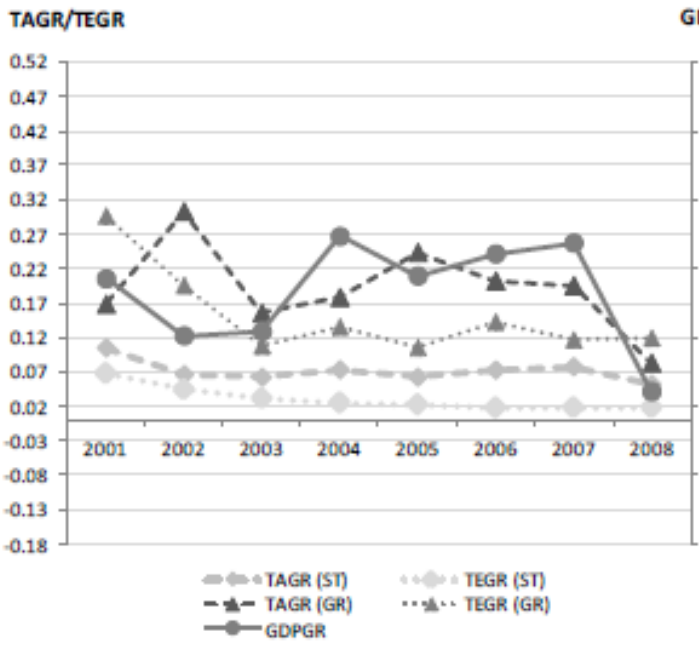

UK
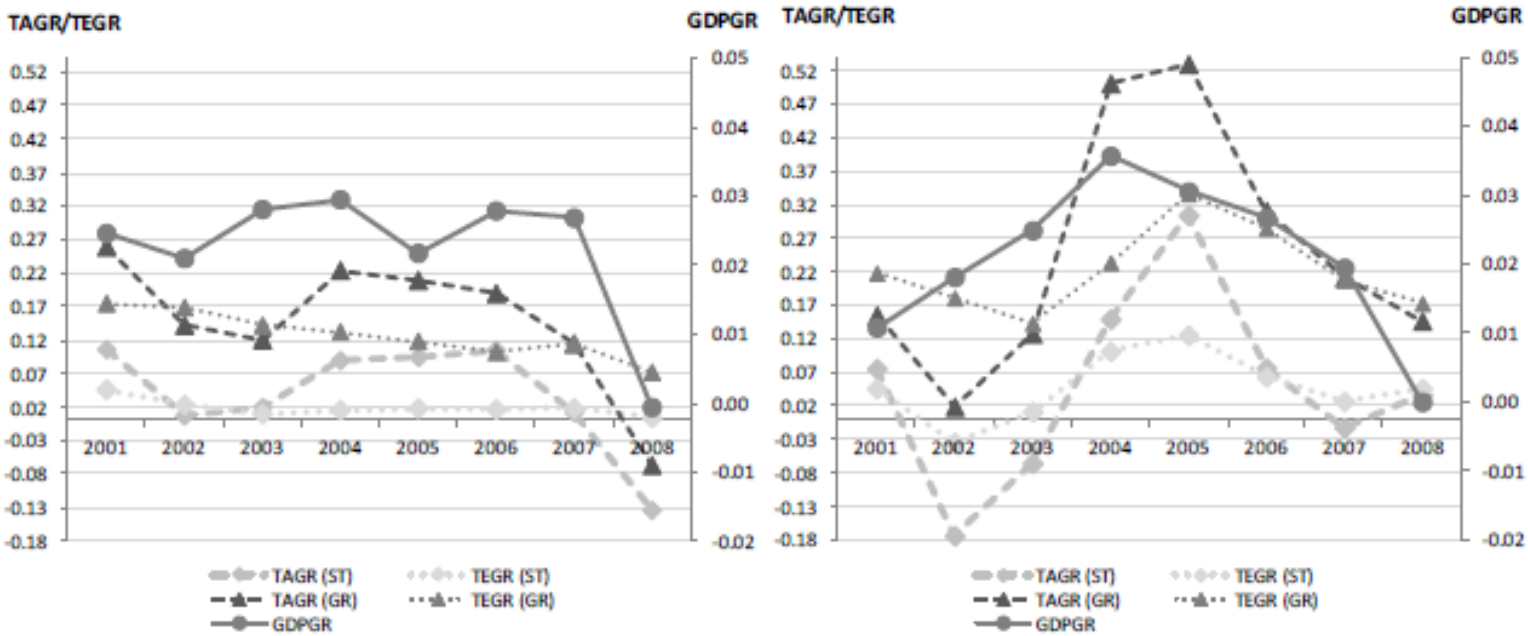

Figure 1. Firm growth rates (mean) and the business cycle per country (2001 - 2008)

TAGR refers to total assets growth and TEGR refers to the growth of total employment. Furthermore, the respective country GDP growth rate is displayed. GDP data are taken from the Statistical Office of the European Communities.

As can be further seen from Table 2, the ST and GR subsamples also differ strongly with respect to total assets, the number of employees and total sales in all countries. It should be noted that the median size (measured by total assets) of a strongly-growing company in the US is more than double the size of GRs in the other country samples. The employment and sales proxies, in contrast, show a more homogeneous picture. This may be explained by the fact that the SME size definition refers to the number of employees and turnover rather than total assets.

Interestingly, Table 3 shows that the continental European samples differ from the UK and US samples with regard to firm age: While French and Italian GRs are slightly older than their ST-counterparts, UK and US' GRs are significantly younger than the STs. Mean ages vary between 20 for US GRs and 29 for UK STs.

While all US firms are listed, i.e. both GRs and STs, only a fraction of the GRs in the UK, in France, and in Italy are listed companies. The number of shareholders is larger for GRs in all but the Italian sample. Overall, this may lead us to conclude that STs display a more concentrated ownership than GRs. We also observe that family ownership is more frequent among STs than GRs, whereas employee ownership is more often found among the GRs. 
Interestingly, while net income is consistently higher for GRs than for STs, profitability (i.e. net income divided by total sales) is higher for STs in all but the US sample. Cross-country, we find that profitability is highest for UK STs, followed by French STs.

Table 2. Descriptive statistics of the firm sample (part I/III)

\begin{tabular}{|c|c|c|c|c|c|c|c|c|c|}
\hline Variable & Sample & & $\mathrm{N}$ & Mean & Median & Min & $\operatorname{Max}$ & Std.Dev & $\mathrm{p}$-value \\
\hline \multirow[t]{8}{*}{ TAGR } & \multirow[t]{2}{*}{ FR } & ST & 26,768 & 0.07 & 0.04 & -0.85 & 4.30 & 0.20 & \multirow[t]{2}{*}{.00} \\
\hline & & GR & 592 & 0.19 & 0.12 & -0.48 & 3.08 & 0.35 & \\
\hline & \multirow[t]{2}{*}{ IT } & $\mathrm{ST}$ & 128,640 & 0.08 & 0.05 & -0.89 & 9.09 & 0.22 & \multirow[t]{2}{*}{.00} \\
\hline & & GR & 6,184 & 0.16 & 0.16 & -0.42 & 9.60 & 0.37 & \\
\hline & \multirow[t]{2}{*}{ UK } & $\mathrm{ST}$ & 55,592 & 0.04 & 0.01 & -0.91 & 19.19 & 0.30 & \multirow[t]{2}{*}{.00} \\
\hline & & GR & 4,456 & 0.15 & 0.09 & -0.58 & 5.53 & 0.33 & \\
\hline & \multirow[t]{2}{*}{ US } & $\mathrm{ST}$ & 2,168 & 0.05 & -0.03 & -0.77 & 4.40 & 0.42 & \multirow[t]{2}{*}{.00} \\
\hline & & GR & 696 & 0.25 & 0.09 & -0.59 & 15.87 & 0.81 & \\
\hline \multirow[t]{8}{*}{ TEGR } & \multirow[t]{2}{*}{ FR } & ST & 26,768 & 0.03 & 0.00 & -0.94 & 7.00 & 0.19 & \multirow[t]{2}{*}{.00} \\
\hline & & GR & 592 & 0.15 & 0.06 & -0.59 & 2.32 & 0.32 & \\
\hline & \multirow[t]{2}{*}{$\mathrm{IT}$} & ST & 128,640 & 0.05 & 0.00 & -0.96 & 12.75 & 0.31 & \multirow[t]{2}{*}{.00} \\
\hline & & GR & 6,184 & 0.11 & 0.05 & -0.96 & 13.25 & 0.44 & \\
\hline & \multirow[t]{2}{*}{$\mathrm{UK}$} & ST & 55,592 & 0.02 & 0.00 & -0.97 & 10.83 & 0.19 & \multirow[t]{2}{*}{.00} \\
\hline & & GR & 4,456 & 0.13 & 0.07 & -0.76 & 5.58 & 0.31 & \\
\hline & \multirow[t]{2}{*}{ US } & ST & 2,168 & 0.05 & 0.00 & -0.77 & 3.00 & 0.31 & \multirow[t]{2}{*}{.00} \\
\hline & & GR & 696 & 0.22 & 0.12 & -0.67 & 6.13 & 0.53 & \\
\hline \multirow{8}{*}{$\begin{array}{l}\text { Total } \\
\text { assets }\end{array}$} & \multirow[t]{2}{*}{ FR } & ST & 30,114 & 3,908 & 1,310 & 19 & 803,541 & 17,649 & \multirow[t]{2}{*}{.00} \\
\hline & & GR & 666 & 133,564 & 30,556 & 816 & $19,000,000$ & $1,106,861$ & \\
\hline & \multirow[t]{2}{*}{ IT } & ST & 144,720 & 9,501 & 6,207 & 72 & $1,784,236$ & 18,145 & \multirow[t]{2}{*}{.00} \\
\hline & & GR & 6,957 & 44,104 & 32,516 & 1,149 & $1,039,017$ & 56,209 & \\
\hline & \multirow[t]{2}{*}{ UK } & ST & 62,541 & 14,332 & 5,696 & 1 & $5,044,853$ & 70,961 & .00 \\
\hline & & GR & 5,013 & 69,263 & 31,018 & 787 & $3,071,563$ & 165,806 & \\
\hline & US & ST & 2,439 & 28,419 & 14,830 & 223 & 547,760 & 43,271 & .00 \\
\hline & & GR & 783 & 142,057 & 71,805 & 2,183 & $4,963,234$ & 288,324 & \\
\hline Total & FR & ST & 30,114 & 31 & 15 & 1 & 463 & 44 & .00 \\
\hline employ- & & GR & 666 & 246 & 173 & 1 & 2,622 & 256 & \\
\hline ment & IT & ST & 144,720 & 42 & 28 & 1 & 488 & 44 & .00 \\
\hline & & GR & 6,957 & 149 & 112 & 2 & 3,577 & 160 & \\
\hline & UK & ST & 62,541 & 70 & 43 & 1 & 496 & 80 & .00 \\
\hline & & GR & 5,013 & 315 & 216 & 2 & 3,971 & 325 & \\
\hline & US & ST & 2,439 & 89 & 73 & 1 & 499 & 75 & .00 \\
\hline & & GR & 783 & 330 & 236 & 3 & 2,511 & 336 & \\
\hline Total & $\mathrm{FR}$ & ST & 30,114 & 5,410 & 2,360 & 11 & 49,708 & 7,517 & .00 \\
\hline sales & & GR & 666 & 63,211 & 50,413 & 2,450 & $1,096,278$ & 70,960 & \\
\hline & IT & ST & 144,720 & 10,420 & 7,802 & 25 & 49,957 & 8,872 & .00 \\
\hline & & GR & 6,957 & 53,961 & 49,971 & 1,432 & 419,274 & 29,107 & \\
\hline & UK & ST & 62,541 & 10,844 & 7,788 & 1 & 49,998 & 10,544 & .00 \\
\hline & & GR & 5,013 & 63,582 & 54,617 & 2,139 & 876,923 & 54,617 & \\
\hline & US & ST & 2,439 & 13,652 & 11,419 & 2 & 49,543 & 10,460 & .00 \\
\hline & & GR & 783 & 97,28417 & 51,633 & 1,375 & $12,800,000$ & 482,435 & \\
\hline
\end{tabular}

$T A G R$ refers to the one year total assets growth rate and TEGR refers to the one year growth rate of total employment. Total assets and total sales are given in thousands of Euros. $N$ refers to the number of observations. p-values of tests on equality of means in the respective country subsamples (STs versus GRs) are reported in the last column. 
Table 3. Descriptive statistics of the firm sample (part II/III)

\begin{tabular}{|c|c|c|c|c|c|c|c|c|c|}
\hline Variable & Sample & & $\bar{N}$ & Mean & Median & Min & Max & Std.Dev & p-value \\
\hline \multirow{8}{*}{$\begin{array}{l}\text { Firm } \\
\text { age }\end{array}$} & \multirow[t]{2}{*}{ FR } & $\mathrm{ST}$ & 30,114 & 22 & 18 & 0 & 198 & 15 & \multirow[t]{2}{*}{.00} \\
\hline & & GR & 666 & 25 & 19 & 1 & 116 & 20 & \\
\hline & \multirow[t]{2}{*}{ IT } & $\mathrm{ST}$ & 144,720 & 24 & 22 & 0 & 908 & 15 & \multirow[t]{2}{*}{.00} \\
\hline & & GR & 6,957 & 25 & 22 & 1 & 103 & 13 & \\
\hline & \multirow[t]{2}{*}{ UK } & $\mathrm{ST}$ & 62,541 & 29 & 21 & 0 & 147 & 25 & \multirow[t]{2}{*}{.00} \\
\hline & & GR & 5,013 & 27 & 20 & 0 & 110 & 23 & \\
\hline & \multirow[t]{2}{*}{ US } & $\mathrm{ST}$ & 2.439 & 29 & 22 & 0 & 192 & 24 & \multirow[t]{2}{*}{.00} \\
\hline & & GR & 783 & 20 & 16 & 0 & 60 & 14 & \\
\hline \multirow{8}{*}{ Public } & \multirow{2}{*}{ FR } & $\mathrm{ST}$ & 30.114 & 0.0 & 0.0 & 0.0 & 1.0 & 0.1 & \multirow[t]{2}{*}{.00} \\
\hline & & GR & 666 & 0.3 & 0.0 & 0.0 & 1.0 & 0.5 & \\
\hline & \multirow[t]{2}{*}{ IT } & $\mathrm{ST}$ & 144,720 & 0.0 & 0.0 & 0.0 & 1.0 & 0.0 & \multirow[t]{2}{*}{.00} \\
\hline & & GR & 6,957 & 0.0 & 0.0 & 0.0 & 1.0 & 0.1 & \\
\hline & \multirow[t]{2}{*}{ UK } & $\mathrm{ST}$ & 62,541 & 0.0 & 0.0 & 0.0 & 1.0 & 0.1 & \multirow[t]{2}{*}{.00} \\
\hline & & GR & 5.013 & 0.1 & 0.0 & 0.0 & 1.0 & 0.2 & \\
\hline & \multirow[t]{2}{*}{ US } & $\mathrm{ST}$ & 2,439 & 1.0 & 1.0 & 1.0 & 1.0 & 0.0 & \\
\hline & & GR & 783 & 1.0 & 1.0 & 1.0 & 1.0 & 0.0 & \\
\hline \multirow{8}{*}{$\begin{array}{l}\text { Number } \\
\text { of } \\
\text { share- } \\
\text { holders }\end{array}$} & \multirow[t]{2}{*}{ FR } & $\mathrm{ST}$ & 30,114 & 2 & 1 & 1 & 24 & 2 & \multirow[t]{2}{*}{.00} \\
\hline & & GR & 666 & 7 & 2 & 1 & 60 & 11 & \\
\hline & \multirow[t]{2}{*}{ IT } & $\mathrm{ST}$ & 144,720 & 4 & 3 & 1 & 128 & 7 & \multirow[t]{2}{*}{.21} \\
\hline & & GR & 6.957 & 4 & 2 & 1 & 122 & 8 & \\
\hline & \multirow[t]{2}{*}{ UK } & $\mathrm{ST}$ & 62,541 & 3 & 2 & 1 & 60 & 4 & .00 \\
\hline & & GR & 5,013 & 6 & 2 & 1 & 112 & 14 & \\
\hline & US & $\mathrm{ST}$ & 2.439 & 13 & 9 & 1 & 91 & 13 & .00 \\
\hline & & GR & 783 & 52 & 51 & 1 & 112 & 32 & \\
\hline Type & FR & ST & 30,114 & 0.6 & 1.0 & 0.0 & 1.0 & 0.5 & .00 \\
\hline & & GR & 666 & 0.3 & 0.0 & 0.0 & 1.0 & 0.5 & \\
\hline Share- & IT & ST & 144,720 & 0.8 & 1.0 & 0.0 & 1.0 & 0.4 & .00 \\
\hline holder & & GR & 6.957 & 0.6 & 1.0 & 0.0 & 1.0 & 0.5 & \\
\hline (IF) & UK & ST & 62,541 & 0.5 & 0.0 & 0.0 & 1.0 & 0.5 & .00 \\
\hline & & GR & 5.013 & 0.4 & 0.0 & 0.0 & 1.0 & 0.5 & \\
\hline & US & $\mathrm{ST}$ & 2,439 & 0.4 & 0.0 & 0.0 & 1.0 & 0.5 & .00 \\
\hline & & GR & 783 & 0.2 & 0.0 & 0.0 & 1.0 & 0.4 & \\
\hline Type & FR. & $\mathrm{ST}$ & 30,114 & 0.005 & 0.000 & 0.0 & 1.0 & 0.1 & .00 \\
\hline & & GR & 666 & 0.027 & 0.000 & 0.0 & 1.0 & 0.2 & \\
\hline Share- & IT & $\mathrm{ST}$ & 144,720 & 0.000 & 0.000 & 0.0 & 0.0 & 0.0 & .00 \\
\hline holder & & GR & 6,957 & 0.001 & 0.000 & 0.0 & 1.0 & 0.0 & \\
\hline (EM) & UK & $\mathrm{ST}$ & 62,541 & 0.003 & 0.000 & 0.0 & 1.0 & 0.1 & .00 \\
\hline & & GR & 5,013 & 0.018 & 0.000 & 0.0 & 1.0 & 0.1 & \\
\hline & US & $\mathrm{ST}$ & 2.439 & 0.000 & 0.000 & 0.0 & 0.0 & 0.0 & \\
\hline & & GR & 783 & 0.000 & 0.000 & 0.0 & 0.0 & 0.0 & \\
\hline
\end{tabular}

Public is a dummy variable that values takes either 1 or 0. Type of Shareholder (IF) and Type of Shareholder (EM) are dummy variables that values take either 1 or $0 . N$ refers to the number of observations. p-values of tests on equality of means in the respective country subsamples (GRs versus STs) are reported in the last column.

Table 4. Descriptive statistics of the firm sample (part III/III)

\begin{tabular}{|l|llr|rrrrr|r|}
\hline \hline Variable & Sample & & $\mathrm{N}$ & Mean & Median & Min & Max & Std.Dev & p-value \\
\hline Net & FR & ST & 30,114 & 257 & 64 & 23,362 & 279,698 & 2,316 & .02 \\
& & GR & 666 & 4,395 & 1,348 & $-556,524$ & 792,669 & 46,903 & \\
& IT & ST & 144,720 & 218 & 56 & $-50,984$ & 967,196 & 2,786 & .00 \\
& & GR & 6,957 & 1,329 & 542 & $-79,660$ & 67,625 & 3,710 & \\
& UK & ST & 62,226 & 649 & 200 & $-669,840$ & $3,427,396$ & 14,683 & .00 \\
& US & GR & 5,011 & 3,514 & 1,581 & $-545,067$ & 379,366 & 16,725 & \\
& & ST & 2,439 & $-2,918$ & -36 & $-376,519$ & 125,306 & 14,633 & .04 \\
\hline Profit- & FR & ST & 783 & -482 & 1,725 & $-327,703$ & 146,810 & 31,117 & \\
ability & & GR & 666 & 0.06 & 0.03 & -18.85 & 255.20 & 1.52 & .05 \\
& IT & ST & 144,720 & 0.02 & 0.03 & -0.51 & 1.04 & 0.11 & \\
& & GR & 6,957 & 0.03 & 0.01 & -7.06 & 49.54 & 0.21 & .00 \\
& UK & ST & 62,226 & 0.11 & 0.04 & -141.30 & 473.53 & 2.68 & .00 \\
& & GR & 5,011 & 0.04 & 0.03 & -6.68 & 4.16 & 0.23 & \\
& US & ST & 2,439 & -1.76 & -0.01 & -643.50 & 29.38 & 17.49 & .00 \\
& & GR & 783 & -0.23 & 0.04 & -36.90 & 1.49 & 2.01 & \\
\hline Equity & FR & ST & 30,114 & 0.39 & 0.37 & 0.00 & 0.99 & 0.19 & .00 \\
ratio & & GR & 666 & 0.34 & 0.33 & 0.02 & 0.98 & 0.17 & \\
& IT & ST & 144,720 & 0.28 & 0.23 & 0.00 & 1.00 & 0.19 & .00 \\
& & GR & 6,957 & 0.26 & 0.21 & 0.00 & 0.98 & 0.17 & \\
& UK & ST & 62,541 & 0.48 & 0.47 & 0.00 & 1.00 & 0.24 & .00 \\
& & GR & 5,013 & 0.37 & 0.34 & 0.01 & 1.00 & 0.21 & \\
& US & ST & 2,439 & 0.66 & 0.70 & 0.01 & 0.99 & 0.21 & .01 \\
& & GR & 783 & 0.64 & 0.69 & 0.03 & 0.99 & 0.20 & \\
\hline \hline
\end{tabular}


Net income is given in thousands of Euros. Profitability is calculated as net income divided by total sales. $N$ refers to the number of observations. p-values of tests on equality of means in the respective country subsamples (GRs versus STs) are reported in the last column.

With regard to industry affiliation, the samples differ significantly by country. However, most companies are active in the manufacturing and wholesale industries. (Note 8)

Finally, we observe that in all countries GRs display lower equity ratios than STs. Equity ratios are highest in UK and US STs. Within the cross-country comparison, it is interesting to note that US STs display the highest equity ratios of 0.66 at the mean, and Italian GRs the lowest mean equity ratio of 0.26 . The development of the mean equity ratios over time is also displayed in Figure 2. It shows that in all countries but the US, particularly the STs strongly increased their equity ratios over the sampling period. In the US, in contrast, both GRs and STs kept their equity ratios almost stable, albeit at a much higher level than in the other countries. Overall, hence, the descriptive statistics appear to support the conjecture that SMEs fall into two distinct groups that indeed differ in their growth.

\section{France}

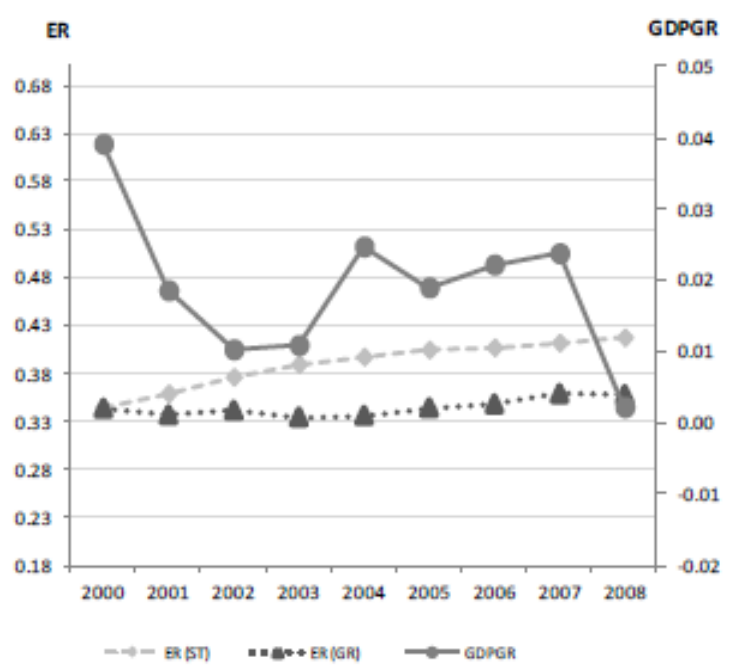

UK

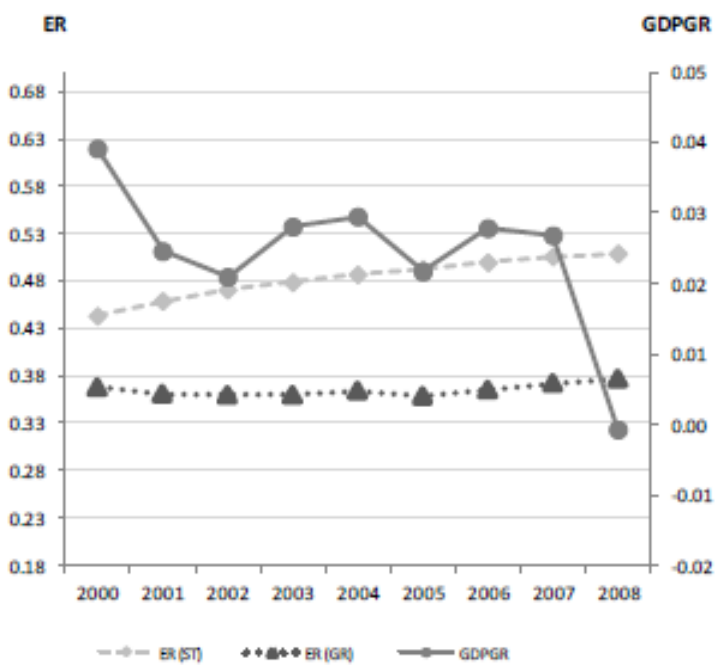

\section{Italy}

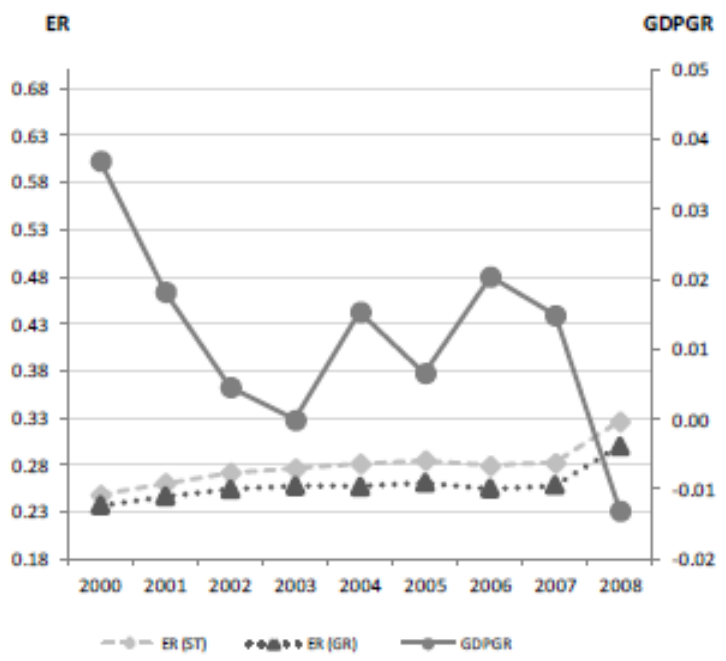

US

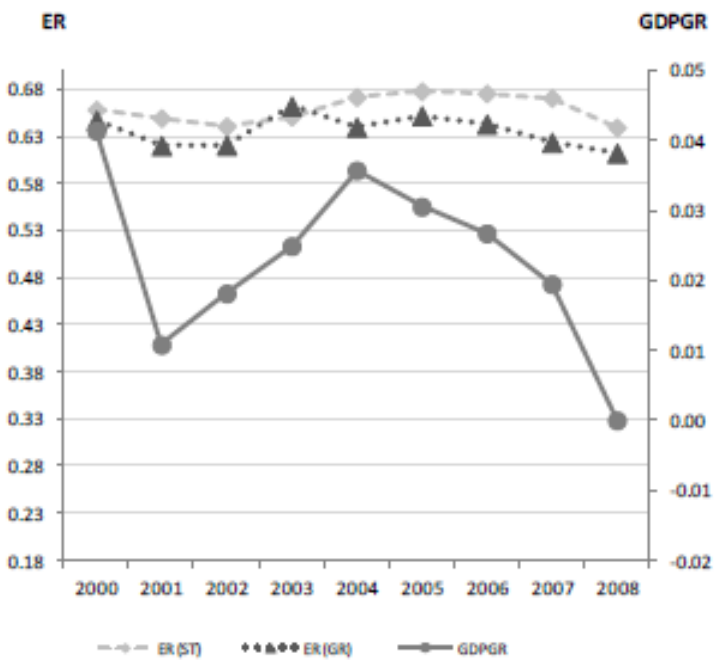

Figure 2. Equity ratios (mean) and business cycle per country (2000 - 2008)

$E R(S T)$ refers to the equity ratio of the ST sample, $E R(G R)$ refers to the equity ratio of the GR sample. Furthermore, the respective country GDP growth rate is displayed. GDP data are taken from the Statistical Office of the European Communities. 
The following Section presents the results of growth regression (2). Section 5.1 gives the findings for total balance sheet growth, Section 5.2 refers to the regression on employment growth.

\section{Results}

\subsection{Balance Sheet Growth}

Regression results are given in Tables 5, 6, 7 and 8 for France, Italy, the UK and the US, respectively. In all tables, models I and III contain the level of GDP as explanatory factor, whereas models II and IV consider the GDP growth rate instead. Models III and IV contain the equity ratio as additional regressor. Since earlier work has shown that consideration of capital structure information may change the effect that other explanatory factors have in growth regressions, we use the capital structure variable only in these two separate regressions. In the following, we will discuss the results along the earlier split of growth factors into firm-inherent determinants, endogenous and exogenous growth factors as presented in Section 2.

\section{Inherent growth determinants}

Firm size effects

Confirming earlier studies, we find strong evidence of a negative relationship between firm size and growth as displayed by highly significant negative coefficients of the lagged size variable (L.LogSIZEta) for both sub-samples (STs and GRs) in all countries.

Firm age effects

We observe only ambiguous age effects on firm growth. A significant negative dependence of balance sheet growth on firm age $(\log A G E)$ is found for French and UK STs. This negative effect levels off for UK STs with higher age as displayed by the significant positive coefficient of the squared age variable (LogAGE2). Italian STs, in contrast, show a weakly significant positive age-growth relationship. Among the GRs, only the French firms display a weakly significant (positive) effect of the squared age variable $(\log A G E 2)$.

Our findings conform well with results from research on conditional firm size and age correlations with growth (Cooley and Quadrini, 2001; Hopenhayn, 1992). As already pointed out by Huynh and Petrunia (2010), the inclusion of further heterogenous variables in the firm growth equation can reduce the economic significance of firm age. This is exactly what our results show as, e.g., the coefficients in the French and UK ST samples are no longer significant when the equity ratio $(E R)$ is included into our firm growth equation (models III and IV, respectively).

\section{Endogenous growth determinants}

Ownership structure effects

According to the literature, a stock listing (PUBLIC) may be expected to induce positive growth effects (Arthurs and Busenitz, 2006; Florin, 2005). Indeed, this is exactly what the significant positive coeffcients for French, Italian and UK STs as well as for French and UK GRs confirm (Note 9).

With regard to ownership concentration, we detect that a less concentrated ownership structure (i.e. an increased number of shareholders, $(N U M B S H))$ positively impacts balance sheet growth for all GR samples. The same effect is found for Italian and US STs. It should be noted that the employed econometric method accounts for the potential causality problem between ownership concentration and firm growth. Thus, we may conclude that a lower concentration indeed positively impacts firm growth and not vice versa. These results confirm the descriptive statistics that already indicated a positive relationship between balance sheet growth and the number of owners. Interestingly, we observe somewhat contrary effects of the number of shareholders on balance sheet growth of UK STs. According to models III and IV, balance sheet growth of UK STs' increases with a less concentrated ownership structure while according to models I and II, which do not employ the capital structure measure, balance sheet growth appears to be negatively impacted by an increased number of shareholders (NUMBSH). We hence identify a consistent positive effect of a decreased ownership concentration for GRs, but not for STs.

From the descriptive statistics, we know that GRs display a smaller fraction of shareholdings by families/individuals than STs. This univariate result is confirmed by weakly significant negative coefficients of the TYPSHIF-variable for Italian GRs. We do not find further significant effects for GRs, though. However, we detect opposing effects in the ST samples: while Italian STs' balance sheet growth suffers from shareholdings of families/individuals as well, we find that French and UK STs are positively affected. Our results are hence in line with the literature that discusses the impact of family control controversially (Hamelin and Trojman, 2007).

Employee participation may be assumed to provide employees with additional incentives to foster firm growth. 
Unfortunately, we cannot draw any conclusions for US GRs as well as US and Italian STs because these samples do not contain any firms with employee ownership participation. However, from the descriptive statistics we know that French and UK GRs show a larger proportion of shareholdings by employees than the respective ST samples (see Table 3 in Section 4). This univariate result is confirmed in the regression: employee ownership participation (TYPSHEM) has a significant positive effect on the balance sheet growth of French, UK and Italian GRs. In the ST samples, we find a strongly significant (negative) effect only for UK firms. Judging from these observations it appears that GRs are superior in seeking, handling and managing employee participation to support firm growth. Unfortunately, the data does not provide further details on the type of participation - whether the participation is part of an employee stock plan or a sign of entrepreneurial stakes. Therefore, our results should only be seen as an indication with regard to the effects of employee ownership building an interesting area for future research.

\section{Capital structure effects}

Sufficient funding is generally seen as a prerequisite for firm growth. As in early growth stages, firms often do not have access to debt financing, we should expect to find a positive relation between the equity ratio and firm growth. More mature firms, in contrast, may rely on debt financing to a larger degree to finance growth. We should therefore conjecture to observe a negative relationship between the equity ratio $(E R)$ and firm growth for GRs and a positive effect for STs. From our regressions, we observe indeed a negative coefficient of the $E R$-variable for UK, US and Italian GRs but also for UK, Italian and French STs. Surprisingly, we observe a positive effect only for US STs: Their balance sheet growth benefits from an increased equity ratio as displayed by significant positive coefficients of the ER-variable.

\section{Use of earnings effects}

As should have been expected, all firms use their internally generated cash flows to boost growth as displayed by highly significant positive coefficients of the LogSALES-variable. The statistical significance is very strong for all samples. Similarly, we should expect the firm growth rate to rise with profitability $(P R O F)$ as firms retain their earnings (Downie, 1958). This assumption is confirmed by positive coefficients for Italian and French GRs as well as Italian, French and UK STs. In contrast, we detect a significantly negative effect on balance sheet growth for US STs.

\section{Exogenous growth determinants}

With regard to business cycle effects, we find that all STs as well as Italian and UK GRs are affected. Interestingly, the current level of GDP $(G D P)$ has a strongly significant positive influence on French and UK STs' balance sheet growth, whereas it has a negative effect on Italian and US STs. The lagged level of the GDP (L.GDP), in contrast, has exactly the opposite effect. Moreover, the GDP growth rate $(G D P G R)$ has a strongly significant positive impact on French and UK STs, but a negative impact on Italian STs. 
Table 5. France - Effects on total asset growth (2000 - 2008)

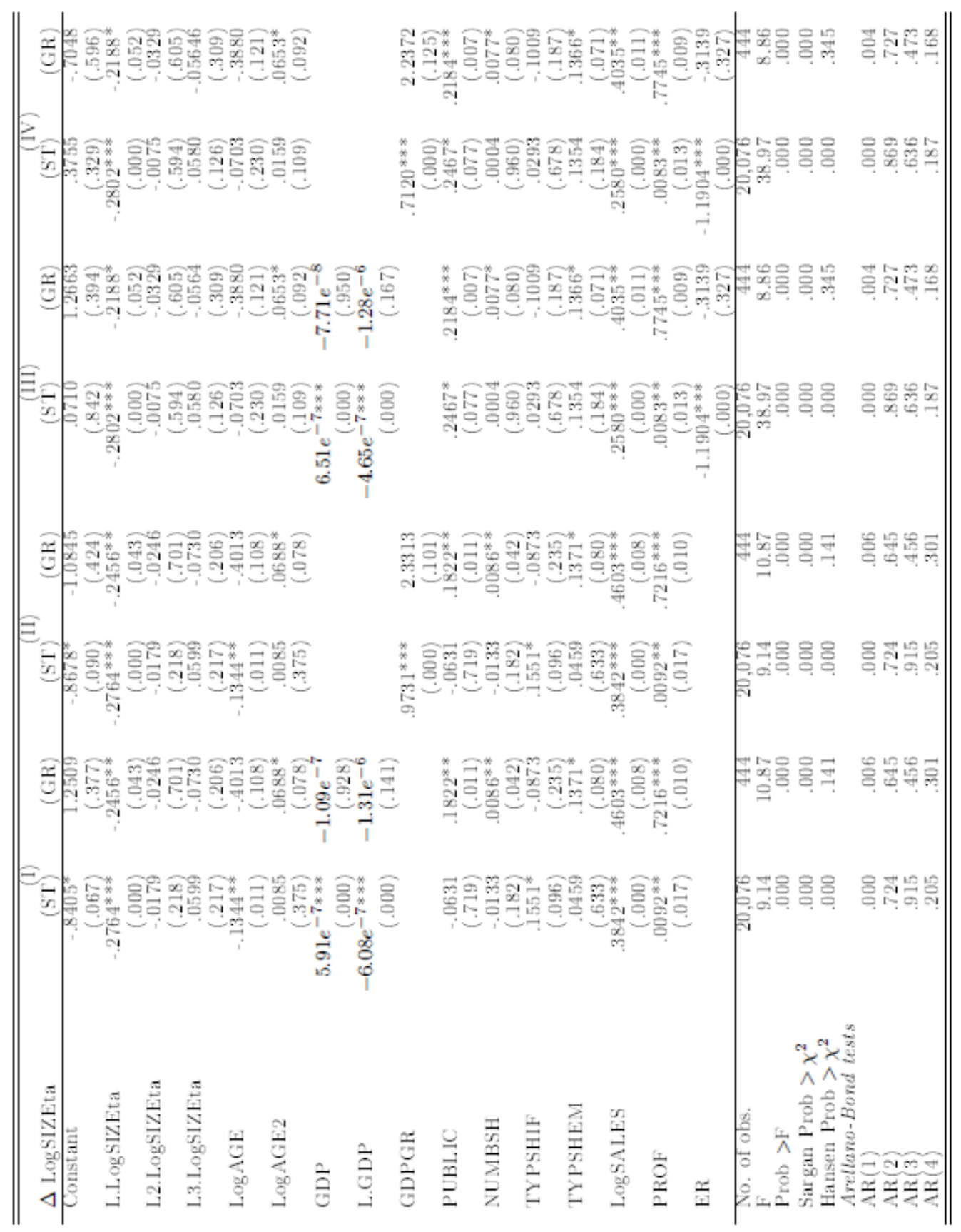

System-GMM regression on the difference of the current and last year's total assets in logs ( $\triangle$ LogSIZEta). LogSIZEta is the natural logarithm of total assets, L. refers to the one-period lag of the LogSIZE variable while L2. and L3. refer to the two- and third-period lag of the LogSIZE variable. LogAGE is the logarithm of firm age, LogAGE2 the squared logarithm of firm age, GDP is the current level of French GDP, L.GDP is the respective one-period lag and GDPGR is the respective French GDP growth rate, PUBLIC is a dummy variable indicating whether a firm is listed $(=1)$ or not $(=0)$, NUMBSH is the number of shareholders, TYPSHIF is a dummy variable indicating whether an individual/family is a shareholder, TYPSHEM is a dummy variable indicating whether an employee is a shareholder, LogSALES is the logarithm of total sales as a proxy for internally generated financial means, PROF is the profitability measured as net income divided by total sales, ER is the equity ratio. The lagged LogSIZE variables, LogSALES, PROF and ER are instrumented. Dummies for the industry sectors indicating whether a firm is active in the secondary or tertiary industry sector as well as time dummies are always included, but results are not displayed. $* * *, * *$, and $*$ indicate significance at the $1 \%, 5 \%$, and $10 \%$ level. p-values are given in parenthesis. 
Table 6. Italy - Effects on total asset growth (2000 - 2008)

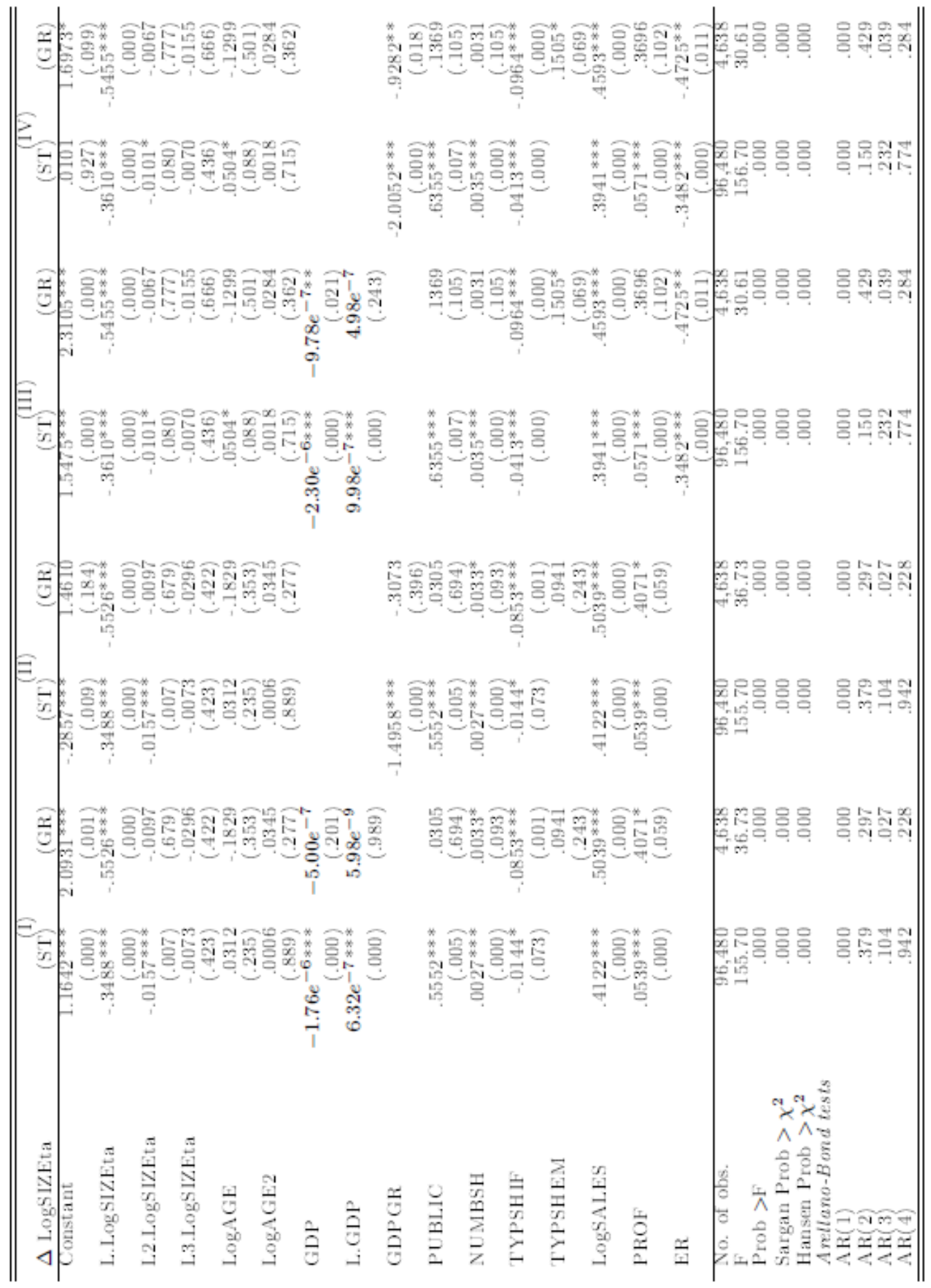

System-GMM regression on the difference of the current and last year's total assets in logs ( $\Delta$ LogSIZEta). LogSIZEta is the natural logarithm of total assets, L. refers to the one-period lag of the LogSIZE variable while L2. and L3. refer to the two- and third-period lag of the LogSIZE variable. LogAGE is the logarithm of firm age, LogAGE2 the squared logarithm of firm age, GDP is the current level of Italian GDP, L.GDP is the respective one-period lag and GDPGR is the respective Italian GDP growth rate, PUBLIC is a dummy variable indicating whether a firm is listed $(=1)$ or not $(=0)$, NUMBSH is the number of shareholders, TYPSHIF is a dummy variable indicating whether an individual/family is a shareholder, TYPSHEM is a dummy variable indicating whether an employee is a shareholder, LogSALES is the logarithm of total sales as a proxy for internally generated financial 
means, PROF is the profitability measured as net income divided by total sales, ER is the equity ratio. The lagged LogSIZE variables, LogSALES, PROF and ER are instrumented. Dummies for the industry sectors indicating whether a firm is active in the secondary or tertiary industry sector as well as time dummies are always included, but results are not displayed. $* * *, * *$, and $*$ indicate significance at the $1 \%, 5 \%$, and $10 \%$ level. p-values are given in parenthesis.

Table 7. UK - Effects on total asset growth (2000 - 2008)

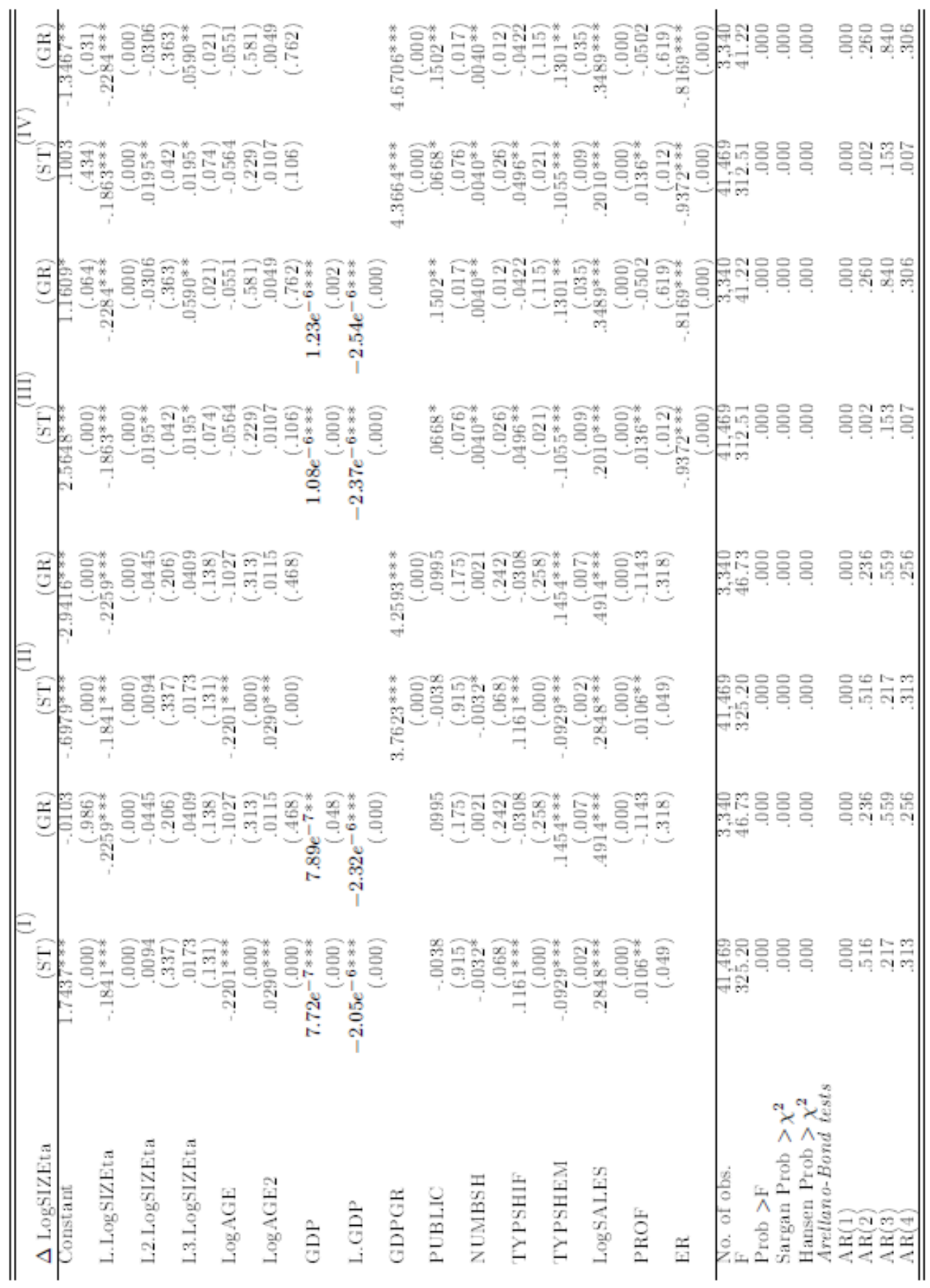

System-GMM regression on the difference of the current and last year's total assets in logs ( $\Delta$ LogSIZEta). LogSIZEta is the natural logarithm of total assets, L. refers to the one-period lag of the LogSIZE variable while L2. and L3. refer to the two- and third-period lag of the LogSIZE variable. LogAGE is the logarithm of firm age, 
LogAGE2 the squared logarithm of firm age, GDP is the current level of UK GDP, L.GDP is the respective one-period lag and GDPGR is the respective UK GDP growth rate, PUBLIC is a dummy variable indicating whether a firm is listed $(=1)$ or not $(=0)$, NUMBSH is the number of shareholders, TYPSHIF is a dummy variable indicating whether an individual/family is a shareholder, TYPSHEM is a dummy variable indicating whether an employee is a shareholder, LogSALES is the logarithm of total sales as a proxy for internally generated financial means, PROF is the profitability measured as net income divided by total sales, ER is the equity ratio. The lagged LogSIZE variables, LogSALES, PROF and ER are instrumented. Dummies for the industry sectors indicating whether a firm is active in the secondary or tertiary industry sector as well as time dummies are always included, but results are not displayed. $* * *, * *$, and $*$ indicate significance at the $1 \%, 5 \%$, and $10 \%$ level. p-values are given in parenthesis.

Table 8. US - Effects on total asset growth (2000 - 2008)

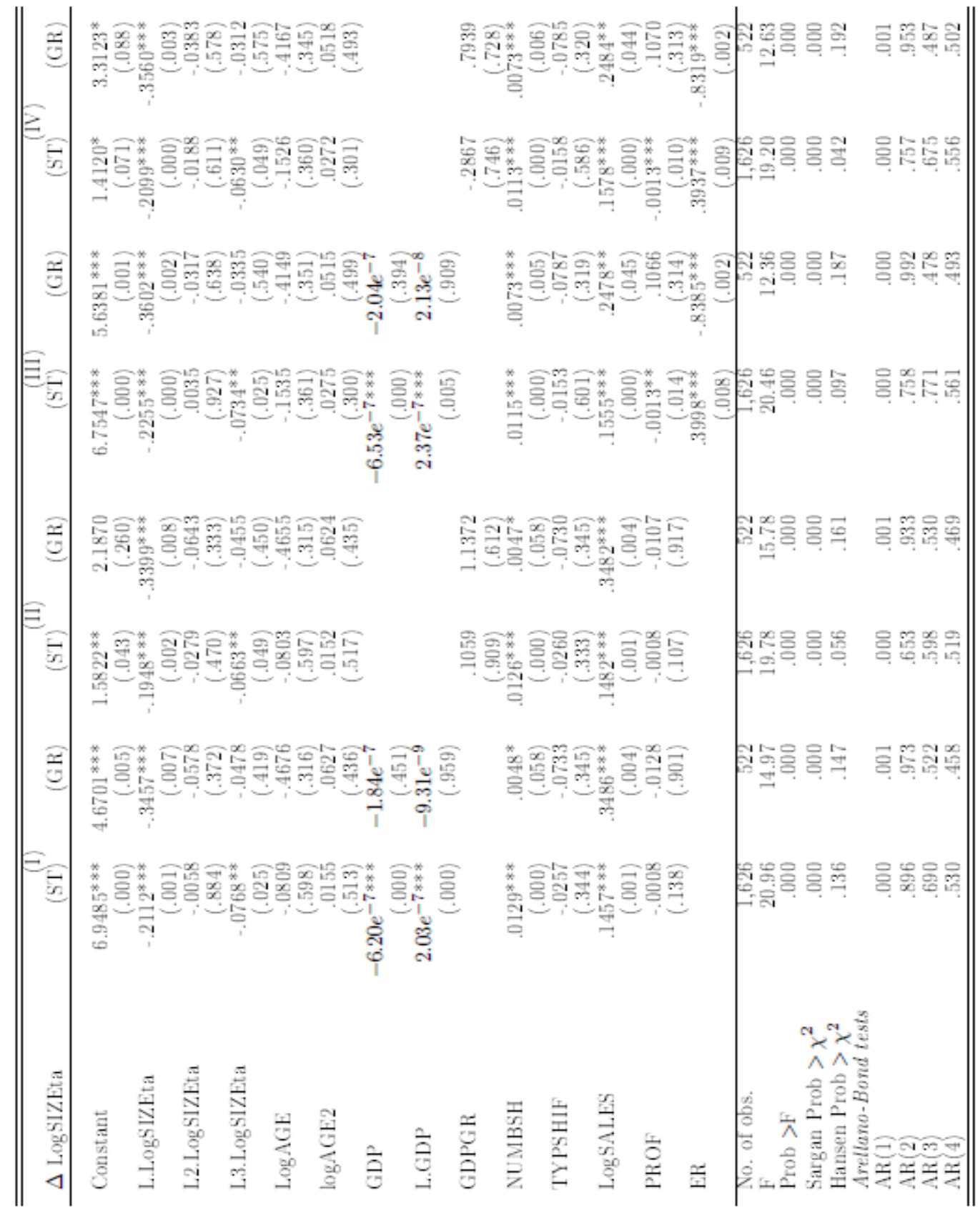

System-GMM regression on the difference of the current and last year's total assets in logs ( $\Delta$ LogSIZEta). LogSIZEta is the natural logarithm of total assets, L. refers to the one-period lag of the LogSIZE variable while L2. and L3. refer to the two- and third-period lag of the LogSIZE variable. LogAGE is the logarithm of firm age, 
LogAGE2 the squared logarithm of firm age, GDP is the current level of US GDP, L.GDP is the respective one-period lag and GDPGR is the respective US GDP growth rate. As all firms in the US sample are publicly listed, the PUBLIC dummy - indicating whether a firm is listed $(=1)$ or not $(=0)$ - is not displayed, NUMBSH is the number of shareholders, TYPSHIF is a dummy variable indicating whether an individual/family is a shareholder. As none of the firms of the US sample display employee shareholders, the TYPSHEM dummy variable - indicating whether an employee is a shareholder - is not displayed. LogSALES is the logarithm of total sales as a proxy for internally generated financial means, PROF is the profitability measured as net income divided by total sales, ER is the equity ratio. The lagged LogSIZE variables, LogSALES, PROF and ER are instrumented. Dummies for the industry sectors indicating whether a firm is active in the secondary or tertiary industry sector as well as time dummies are always included, but results are not displayed. $* * *, * *$, and $*$ indicate significance at the $1 \%, 5 \%$, and $10 \%$ level. p-values are given in parenthesis.

\section{Summary}

Our analyses of firms' balance sheet growth deliver two broad results. First, we observe diverging effects of both inherent, endogenous and exogenous growth factors on STs' and GRs' growth rates. Irrespective of the country, the group of stable SMEs sets itself consistently apart from the group of strongly-growing SMEs. Second, in a cross-country comparison, we find that ownership and capital structure choices display more diverging effects on stable SMEs than on growing SMEs. Inherent growth factors, in contrast, appear to impact the growth of both groups in broadly the same way in the different countries. Strongly-growing firms, as a consequence, seem to develop more homogeneously than stable SMEs. Table 9 summarizes the regression results by displaying the significant growth effects.

We hence conclude that the separate growth analysis of stable versus growing SMEs (STs vs. GRs) as well as an individual focus on the firms' country of origin is crucial to derive concise results. Based on the derivation of strongly diverging effects of endogenous growth factors on stable SMEs, our study hence underlines the particular heterogeneity of this group of firms.

Table 9. Summary results from balance sheet growth regressions

\begin{tabular}{|c|c|c|c|c|c|}
\hline & & France & Italy & UK & US \\
\hline \multirow[t]{2}{*}{ Size } & STs & - & - & - & - \\
\hline & GRs & - & - & - & - \\
\hline \multirow[t]{2}{*}{ Age } & $\mathrm{STs}$ & $(-)$ & $(+)$ & $(-)$ & \\
\hline & GRs & & & & \\
\hline \multirow[t]{2}{*}{ Public } & STs & $(+)$ & + & $(+)$ & \\
\hline & GRs & + & & $(+)$ & \\
\hline \multirow[t]{2}{*}{ Numbsh } & $\mathrm{STs}$ & & + & $(+/-)$ & + \\
\hline & GRs & + & $(+)$ & $(+)$ & + \\
\hline \multirow[t]{2}{*}{ Typshif } & STs & $(+)$ & - & + & \\
\hline & GRs & & - & & \\
\hline \multirow[t]{2}{*}{ Typshem } & STs & & & - & \\
\hline & GRs & + & $(+)$ & + & \\
\hline \multirow[t]{2}{*}{ ER } & STs & - & - & - & + \\
\hline & GRs & & - & - & - \\
\hline \multirow[t]{2}{*}{ Sales } & STs & + & + & + & + \\
\hline & GRs & + & + & + & + \\
\hline \multirow[t]{2}{*}{ Prof } & $\mathrm{STs}$ & + & + & + & $(-)$ \\
\hline & GRs & + & $(+)$ & & \\
\hline \multirow[t]{2}{*}{ GDP } & $\mathrm{STs}$ & + & - & + & - \\
\hline & GRs & & $(-)$ & + & \\
\hline
\end{tabular}

The signs reflect significant regression coefficients with the corresponding sign in all regression models. If significance does not hold for all regression models but shows up only in some, the respective sign is shown in brackets. 


\subsection{Employment Growth}

Results from regressions on employment growth are given in Tables 10, 11, 12 and 13 for France, Italy, UK and the US, respectively.

\section{Inherent growth determinants}

\section{Firm size effects}

The regressions confirm a negative relationship between firm size and growth for all ST samples. Furthermore, we find significant negative coefficients of the lagged size variable (L.LogSIZEte) for French, Italian, UK and US STs and for Italian and French GRs. In contrast, we observe a positive effect of an increased firm size on firm employment growth for UK GRs.

Firm age effects

Similar to the balance sheet regressions, we detect only limited evidence of age effects on firm growth. We observe significant age effects only for UK and US STs. However, these effects are opposing: While employment growth of UK STs decreases with increasing firm age (LogAGE), employment growth increases for US STs. Again, both effects level off with an increased firm age as displayed by positive (negative) coefficients of the squared age variable (LogAGE2) for UK (US) STs.

\section{Endogenous growth determinants}

Ownership structure effects

Employment growth regressions also confirm a positive effect of a listing (PUBLIC) on firm growth. French and UK GRs as well as French STs display the expected significant positive coefficients. The analysis of ownership concentration effects on employment growth delivers a slightly different picture than the earlier investigation of balance sheet growth. Italian STs and GRs are now differently affected by the NUMBSH-variable: Italian GRs show reduced employment growth with an increased number of shareholders, while Italian STs' employment growth benefits from an increased number of shareholders. Furthermore, UK STs' employment growth also decreases along with an increased number of shareholders $(N U M B S H)$ as displayed by weakly significant coefficients. As regards family shareholders, we find hardly any significant effect stemming from the TYPSHIF-variable on the employment growth of GRs. Similar to the analysis of balance

sheet growth, a negative coefficient is only observed for Italian STs. Again, French and UK STs' employment growth benefits from family/individual-shareholders as displayed by significant positive coefficients. Further interesting effects stem from employee ownership (TYPSHEM): Similar to balance sheet growth, employment regressions also confirm that French and UK GRs' growth strongly benefits from employee participations. In contrast, employment growth of Italian GRs seems to decrease if employees are shareholders. We do not observe any significant effects for STs.

\section{Capital structure effects}

Paralleling our results on balance sheet growth, we observe a significantly negative impact of an increased equity ratio $(E R)$ on employment growth for UK, Italian and French STs. For GRs, we again detect significant negative coefficients for the UK, US and Italian samples.

\section{Use of earnings effects}

While the LogSALES-variable shows the same effects as in the earlier balance sheet regressions, the impact of profitability on employment growth differs. As before, Italian STs appear to use their higher profitability (PROF) to boost employment. In contrast, US and French STs seem to use higher profitability to reduce employment. We furthermore find weakly significant negative coefficients of the profitability variable for UK GRs.

\section{Exogenous growth determinants}

The current level of GDP (GDP) only determines the employment growth of UK STs as shown by a negative coefficient. The lagged level of GDP (L.GDP) affects French and Italian STs' employment growth negatively and UK STs' growth positively. Furthermore, French and Italian (UK) STs' employment growth is positively (negatively) impacted by the GDP growth rate(GDPGR). Among GRs, we only find a negative impact on Italian firms from the lagged GDP (L.GDP) and a positive effect from the GDP growth rate (GDPGR). Overall, STs' employment growth appears to be much more affected by business cycle swings than the employment growth of GRs. 
Table 10. France - Effects on total employment growth (2000 - 2008)

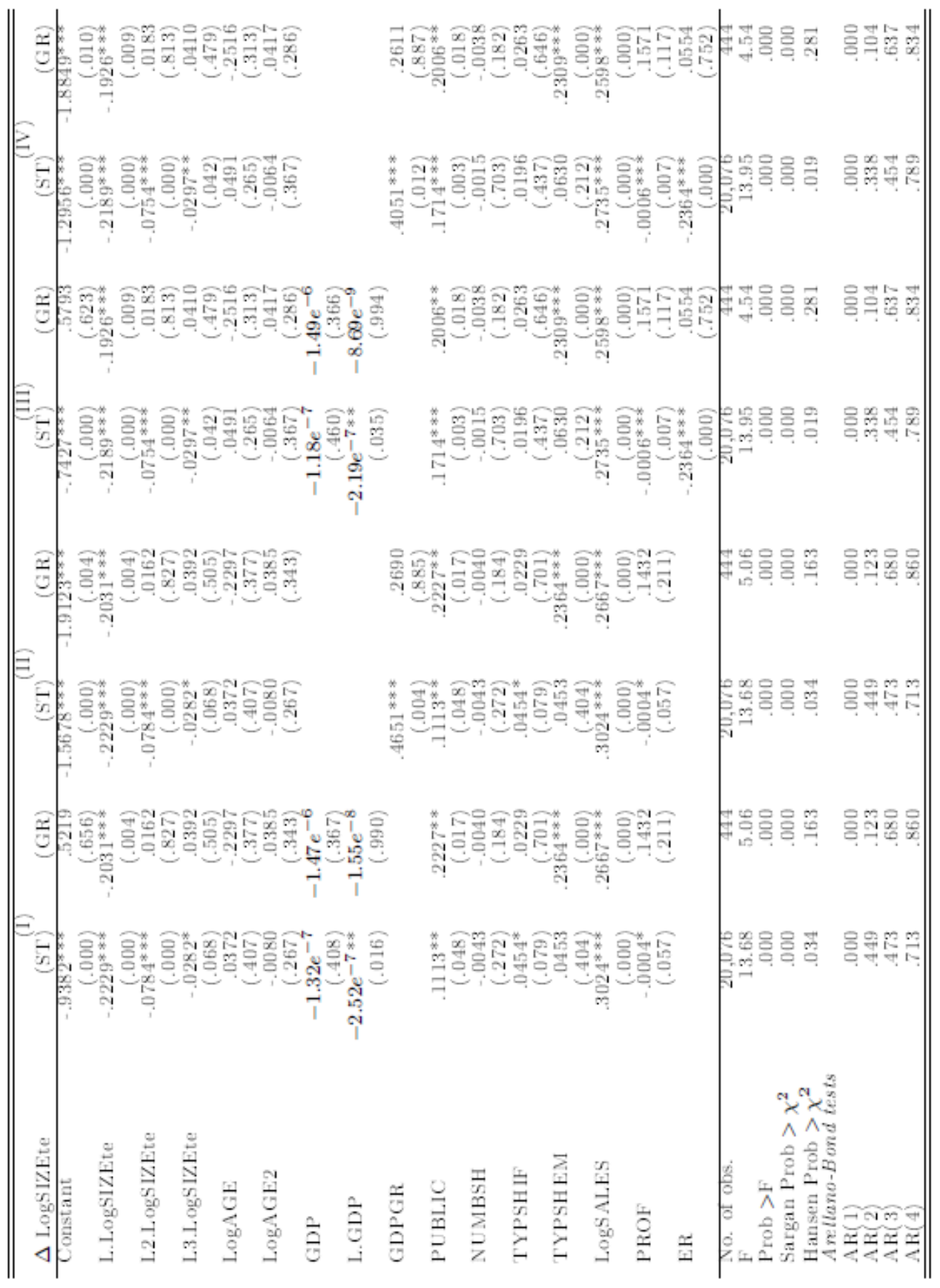

System-GMM regression on the difference of the current and last year's total employment in logs ( $\triangle$ LogSIZEte). LogSIZEte is the natural logarithm of total employees, L. refers to the one-period lag of the LogSIZE variable while L2. and L3. refer to the two- and third-period lag of the LogSIZE variable. LogAGE is the logarithm of firm age, LogAGE2 the squared logarithm of firm age, GDP is the current level of French GDP, L.GDP is the respective one-period lag and GDPGR is the respective French GDP growth rate, PUBLIC is a dummy variable indicating whether a firm is listed $(=1)$ or not $(=0)$, NUMBSH is the number of shareholders, TYPSHIF is a dummy variable indicating whether an individual/family is a shareholder, TYPSHEM is a dummy variable indicating whether an employee is a shareholder, LogSALES is the logarithm of total sales as a proxy for internally generated financial means, PROF is the profitability measured as net income divided by total sales, ER is the equity ratio. The lagged LogSIZE variables, LogSALES, PROF and ER are instrumented. Dummies for the industry sectors indicating whether a firm is active in the secondary or tertiary industry sector as well as time dummies are always included, but 
results are not displayed. $* * *, * *$, and $*$ indicate significance at the $1 \%, 5 \%$, and $10 \%$ level. p-values are given in parenthesis.

Table 11. Italy - Effects on total employment growth (2000 - 2008)

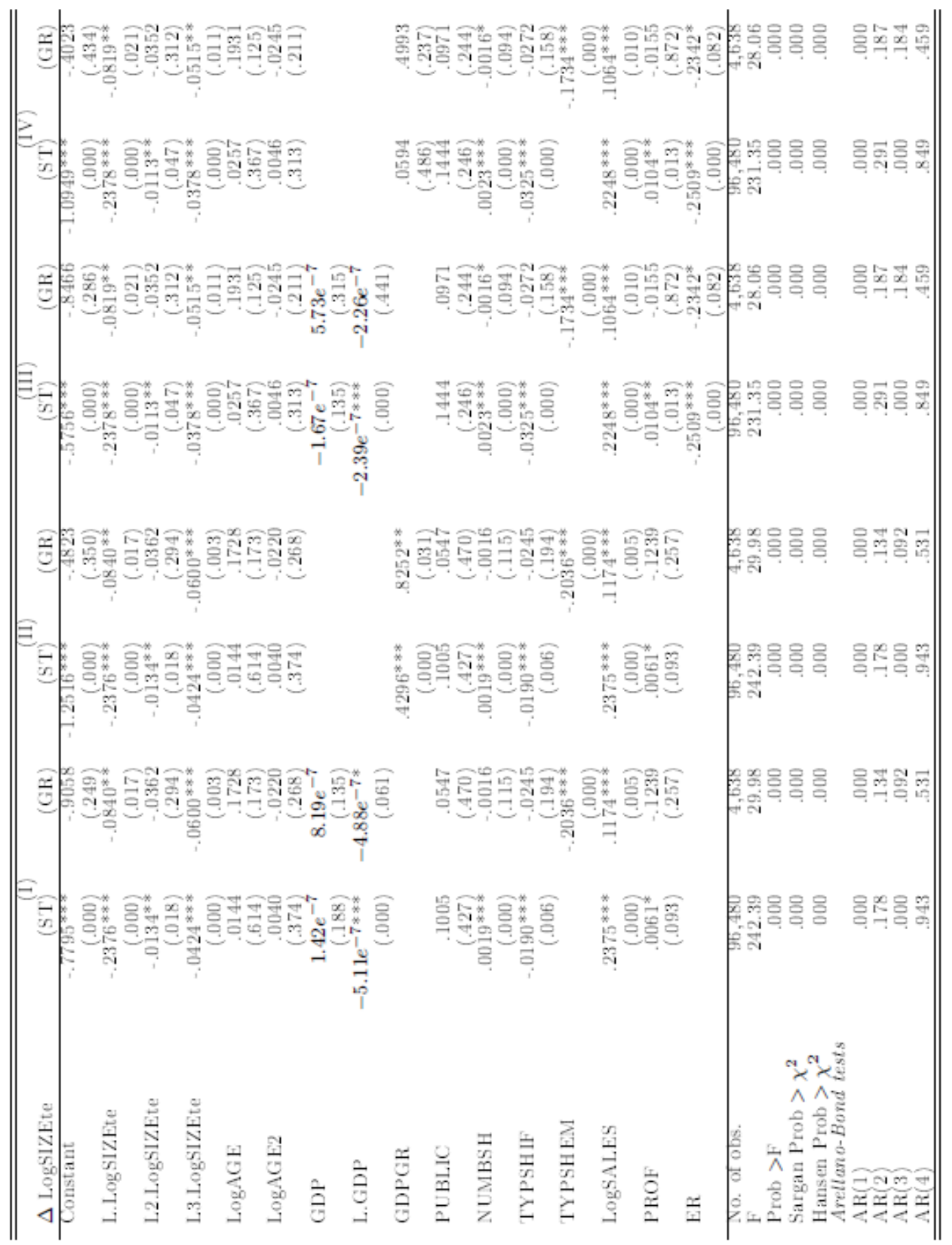

System-GMM regression on the difference of the current and last year's total employment in logs ( $\triangle$ LogSIZEte). LogSIZEte is the natural logarithm of total employees, L. refers to the one-period lag of the LogSIZE variable while L2. and L3. refer to the two- and third-period lag of the LogSIZE variable. LogAGE is the logarithm of firm age, LogAGE2 the squared logarithm of firm age, GDP is the current level of Italian GDP, L.GDP is the respective one-period lag and GDPGR is the respective Italian GDP growth rate, PUBLIC is a dummy variable indicating whether a firm is listed $(=1)$ or not $(=0)$, NUMBSH is the number of shareholders, TYPSHIF is a dummy variable indicating whether an individual/family is a shareholder, TYPSHEM is a dummy variable indicating whether an 
employee is a shareholder, LogSALES is the logarithm of total sales as a proxy for internally generated financial means, PROF is the profitability measured as net income divided by total sales, ER is the equity ratio. The lagged LogSIZE variables, LogSALES, PROF and ER are instrumented. Dummies for the industry sectors indicating whether a firm is active in the secondary or tertiary industry sector as well as time dummies are always included, but results are not displayed. $* * *, * *$, and $*$ indicate significance at the $1 \%, 5 \%$, and $10 \%$ level. p-values are given in parenthesis.

Table 12. UK - Effects on total employment growth (2000 - 2008)

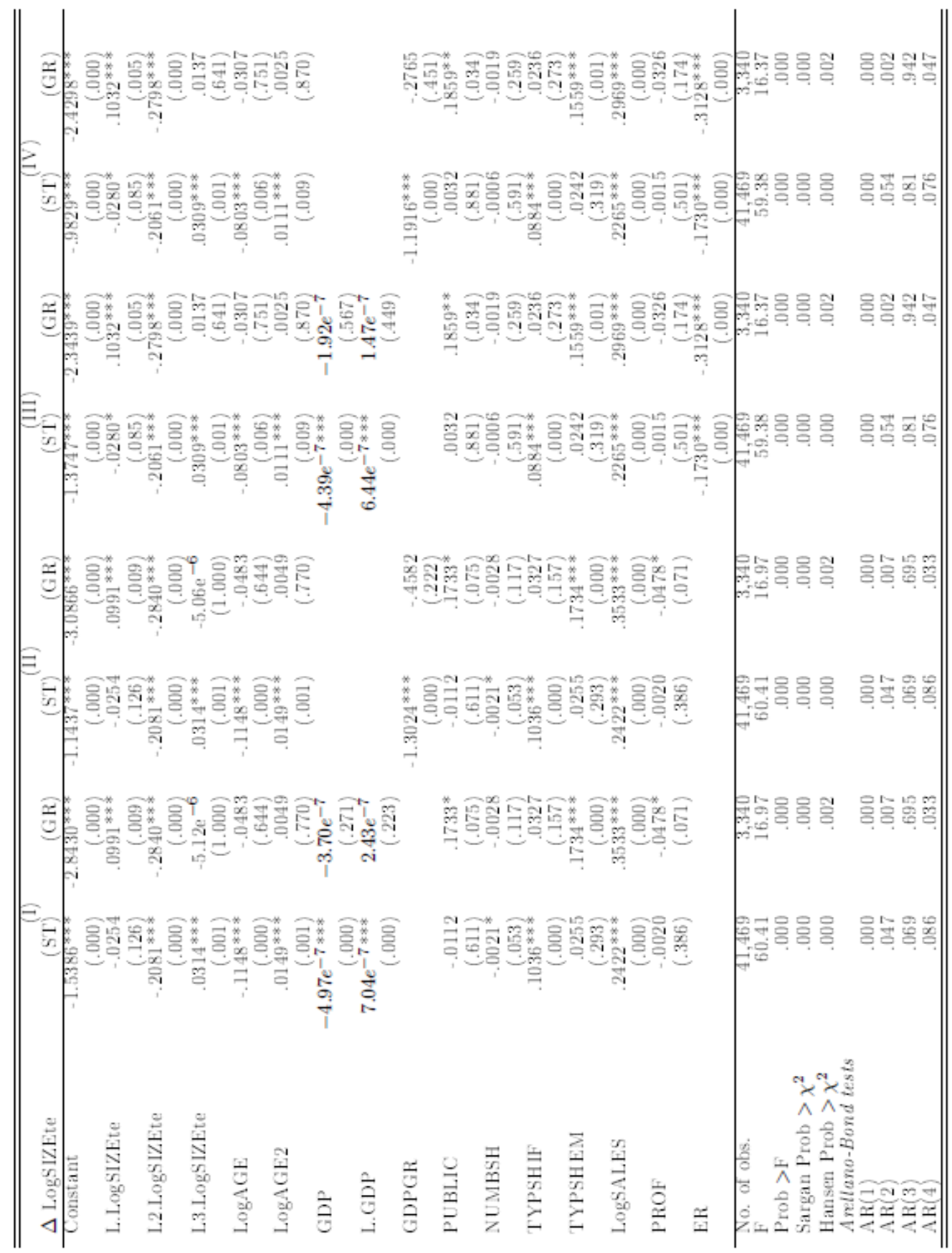

System-GMM regression on the difference of the current and last year's total employment in logs ( $\Delta$ LogSIZEte). LogSIZEte is the natural logarithm of total employees, L. refers to the one-period lag of the LogSIZE variable while L2. and L3. refer to the two- and third-period lag of the LogSIZE variable. LogAGE is the logarithm of firm age, LogAGE2 the squared logarithm of firm age, GDP is the current level of UK GDP, L.GDP is the respective 
one-period lag and GDPGR is the respective UK GDP growth rate, PUBLIC is a dummy variable indicating whether a firm is listed $(=1)$ or not $(=0)$, NUMBSH is the number of shareholders, TYPSHIF is a dummy variable indicating whether an individual/family is a shareholder, TYPSHEM is a dummy variable indicating whether an employee is a shareholder, LogSALES is the logarithm of total sales as a proxy for internally generated financial means, PROF is the profitability measured as net income divided by total sales, ER is the equity ratio. The lagged LogSIZE variables, LogSALES, PROF and ER are instrumented. Dummies for the industry sectors indicating whether a firm is active in the secondary or tertiary industry sector as well as time dummies are always included, but results are not displayed. $* * *, * *$, and * indicate significance at the $1 \%, 5 \%$, and $10 \%$ level. p-values are given in parenthesis.

Table 13. US - Effects on total employment growth (2000 - 2008)

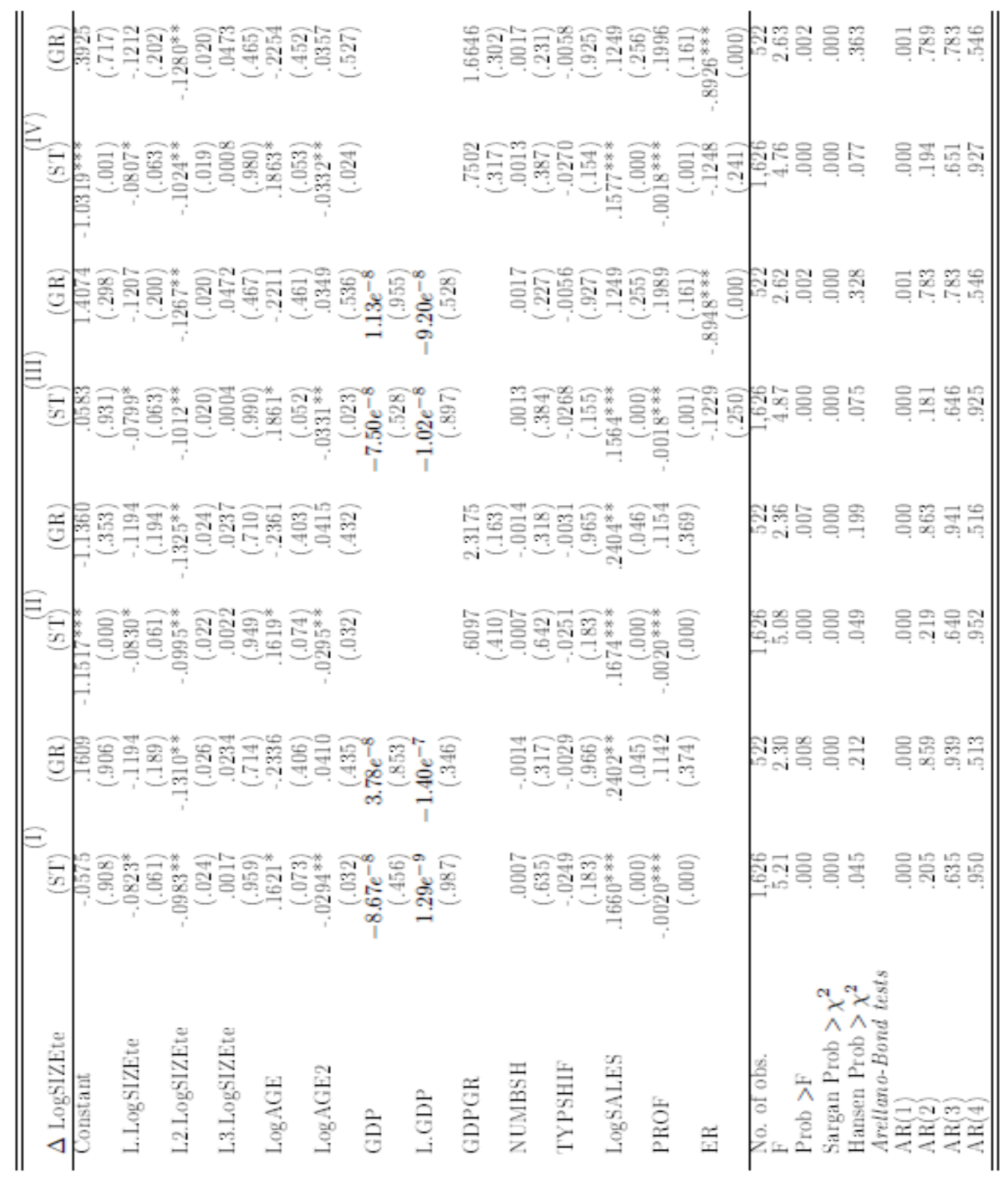

System-GMM regression on the difference of the current and last year's total employment in logs ( $\triangle$ LogSIZEte). LogSIZEte is the natural logarithm of total employees, L. refers to the one-period lag of the LogSIZE variable while L2. and L3. refer to the two- and third-period lag of the LogSIZE variable. LogAGE is the logarithm of firm age, LogAGE2 the squared logarithm of firm age, GDP is the current level of US GDP, L.GDP is the respective one-period lag and GDPGR is the respective US GDP growth rate. As all firms in the US sample are publicly listed, the PUBLIC dummy - indicating whether a firm is listed $(=1)$ or not $(=0)$ - is not displayed, NUMBSH is the number 
of shareholders, TYPSHIF is a dummy variable indicating whether an individual/family is a shareholder. As none of the firms of the US sample display employee shareholders, the TYPSHEM dummy variable - indicating whether an employee is a shareholder - is not displayed. LogSALES is the logarithm of total sales as a proxy for internally generated financial means, PROF is the profitability measured as net income divided by total sales, ER is the equity ratio. The lagged LogSIZE variables, LogSALES, PROF and ER are instrumented. Dummies for the industry sectors indicating whether a firm is active in the secondary or tertiary industry sector as well as time dummies are always included, but results are not displayed. $* * *, * *$, and $*$ indicate significance at the $1 \%, 5 \%$, and $10 \%$ level. p-values are given in parenthesis.

\section{Summary}

Generally, the analysis of employment growth delivers quite similar results to the examination of balance sheet growth. Differences in growth effects of endogenous variables are less pronounced, though. This may be explained by the fact that firms' employment strategies are, apart from growth targets, also strongly dependent on country-specific regulations. Unfortunately, we are not able to fully control for these institutional determinants in this analysis (e.g. different labor laws, lay-off protection rules etc.) (Note 10). Particularly against this backdrop, it is interesting to note that some growth factors such as the capital structure or the listing status display largely homogeneous effects. Table 14 summarizes the regression results for employment growth.

Table 14. Summary results from employment growth regressions

\begin{tabular}{|c|c|c|c|c|c|}
\hline & & France & Italy & UK & US \\
\hline \multirow[t]{2}{*}{ Size } & $\mathrm{STs}$ & - & - & $(-)$ & - \\
\hline & GRs & - & - & + & \\
\hline \multirow[t]{2}{*}{ Age } & $\mathrm{STs}$ & & & - & + \\
\hline & GRs & & & & \\
\hline \multirow[t]{2}{*}{ Public } & STs & + & & & \\
\hline & GRs & + & & + & \\
\hline \multirow[t]{2}{*}{ Numbsh } & STs & & + & $(-)$ & \\
\hline & GRs & & $(-)$ & & \\
\hline \multirow[t]{2}{*}{ Typshif } & STs & & - & + & \\
\hline & GRs & & & & \\
\hline \multirow[t]{2}{*}{ Typshem } & STs & & & & \\
\hline & GRs & + & - & + & \\
\hline \multirow[t]{2}{*}{ ER } & STs & - & - & - & \\
\hline & GRs & & - & - & - \\
\hline \multirow[t]{2}{*}{ Sales } & STs & + & + & + & + \\
\hline & GRs & + & + & + & $(+)$ \\
\hline \multirow[t]{2}{*}{ Prof } & STs & - & + & & - \\
\hline & GRs & & & $(-)$ & \\
\hline \multirow[t]{2}{*}{ GDP } & STs & & & - & \\
\hline & GRs & & & & \\
\hline
\end{tabular}

The signs reflect significant regression coefficients with the corresponding sign in all regression models. If significance does not hold for all regression models but shows up only in some, the respective sign is shown in brackets.

\section{Conclusion}

In addition to confirming some stylized facts on firm growth, we provide empirical evidence that among the group of SMEs two types of firms can reasonably be distinguished: stable SMEs on the one hand and strongly growing firms on the other. We show that the growth processes of both types of firms are partly subject to country-specific growth determinants. 
More importantly, we find that the group of stable SMEs is particularly heterogeneous in its growth behavior. While European SMEs differ mainly in their choice of ownership structures, US SMEs set themselves apart by their choice of capital structure. More precisely, the choice of shareholder type seems to be decisive for European SMEs' growth, while US firms appear to choose particularly high equity ratios in order to support a stable growth process. Growing SMEs, in contrast, display much more uniform growth patterns in all countries.

Our results hence contribute further to the nascent view of SMEs as an assemblage of very diverge companies. Complementing earlier studies, we can show that even though a core group of firms remains within the SME size class, i.e. does not outgrow it, these firms are still extremely heterogeneous in their choice of factors to support their moderate growth.

\section{References}

Almeida, H., Campello, M., \& M. S. Weisbach. (2004). The cash flow sensitivity of cash. Journal of Finance, 59(4), 1777-1804. http://dx.doi.org/10.1111/j.1540-6261.2004.00679.x

Almus, M., \& E. Nerlinger. (2000). Testing Gibrat's law for young firms: empirical results for West Germany. Small Business Economics, 15(1), 1-12. http://dx.doi.org/10.1023/A:1026512005921

Angelini, P., \& A. Generale. (2008). On the evolution of firm size distributions. American Economic Review, 98(1), 426-438. http://dx.doi.org/10.1257/aer.98.1.426

Arellano, M., \& O. Bover. (1995). Another look at the instrumental variable estimation of error components models. Journal of Econometrics, 68(1), 29-51. http://dx.doi.org/10.1016/0304-4076(94)01642-D

Arellano, M., \& S. R. Bond. (1991). Some tests of specification for panel data: Monte Carlo evidence and an application to employment equations. Review of Economic Studies, 58(2), 277-297. http://dx.doi.org/10.2307/2297968

Arthurs, J. D., \& L. W. Busenitz. (2006). Dynamic capabilities and venture performance: the effects of venture capitalists. Journal of Business Venturing, 21(2), 195-215. http://dx.doi.org/10.1016/j.jbusvent.2005.04.004

Audretsch, D. B., Klomp, L., \& A. R. Thurik. (1998). Do services differ from manufacturing? The post-entry performance of firms in Dutch services. Tinbergen Institute Discussion Papers 98-012/3.

Bannier, C. E., \& S. Zahn. (2012). Are SMEs large firms in miniature? Evidence from the growth of German SMEs. International Journal of Entrepreneurship and Small Business, forthcoming. http://dx.doi.org/10.1504/IJESB.2012.048848

Becchetti, L., \& G. Trovato. (2002). The Determinants of Growth for Small and Medium Sized Firms. The Role of the Availability of External Finance. Small Business Economics, 19(4), 291-306. http://dx.doi.org/10.1023/A:1019678429111

Beck, T., Demirguc-Kunt, A., \& V. Maksimovic. (2005). Financial and legal constraints to growth: does firm size matter? Journal of Finance, 60(1), 137-177. http://dx.doi.org/10.1111/j.1540-6261.2005.00727.x

Biosca, A. B. (2010). Growth dynamics: exploring business growth and contraction in Europe and the US. NESTA Research Report November 2010.

Birley, S., \& P. Westhead. (1990). Growth and performance contrasts between 'types' of small firms. Strategic Management Journal, 11(7), 535-557. http://dx.doi.org/10.1002/smj.4250110705

Blundell, R., \& S. Bond. (1998). Initial conditions and moment restrictions in dynamic panel data models. Journal of Econometrics, 87(1), 115-143. http://dx.doi.org/10.1016/S0304-4076(98)00009-8

Boeri, T., \& U. Cramer. (1992). Employment growth, incumbents and entrants: evidence from Germany. International Journal of Industrial Organization, 10(4), 545-565. http://dx.doi.org/10.1016/0167-7187(92)90059-8

Bottazzi, G., \& A. Secchi. (2003). Common properties and sectoral specificities in the dynamics of U.S. manufacturing companies. Review of Industrial Organization, 23(3)-4, 217-232.

Bottazzi, G., Cefis, E., Dosi, G., \& A. Secchi. (2007). Invariances and diversities in the patterns of industrial evolution: some evidence from Italian manufacturing industries. Small Business Economics, 29(1), 137-159.

Bottazzi, G., Dosi, G., Lippi, M., Pammolli, F., \& M. Riccaboni. (2001). Innovation and corporate growth in the evolution of the drug industry. International Journal of Industrial Organization, 19(7), 1161-1187. 
Carpenter, R. E., \& B. C. Petersen. (2002). Is the growth of small firms constrained by internal finance? The Review of Economics and Statistics, 84(2), 298-309. http://dx.doi.org/10.1162/003465302317411541

Chesher, A. (1979). Testing the Law of proportionate effect. Journal of Industrial Economics, 27(4), $403-411$.

Chu, W. (2009). The influence of family ownership on SME performance: evidence from public firms in Taiwan. Small Business Economics, 33(3), 353-373. http://dx.doi.org/10.1007/s11187-009-9178-6

Churchill, N. C., \& V. L. Lewis. (1983). The five stages of small business growth. Harvard Business Review, 61(3), 30-50.

Coad, A. (2007a). A closer look at serial growth rate correlation. Review of Industrial Organization, 31(1), pp.69-82. http://dx.doi.org/10.1007/s11151-007-9135-y

Coad, A. (2007b). Testing the principle of 'growth of the fitter': the relationship between profits and firm growth. Structural Change and Economic Dynamics, 18(3), 370-386. http://dx.doi.org/10.1016/j.strueco.2007.05.001

Coad, A., \& W. Holzl. (2010). Firm growth: empirical analysis. WIFO Working Paper No 361.

Cooley, T. F., \& V. Quadrini. (2001). Financial markets and firm dynamics. American Economic Review, 91(5), 1286-1310. http://dx.doi.org/10.1257/aer.91.5.1286

Costantini, J. (2008). Impact of financial development on firm growth and size. unpublished INSEAD Working Paper.

Das, S. (1995). Size, age and firm growth in an infant industry: The computer hardware industry in India. International Journal of Industrial $\quad$ Organization, $13(1), \quad$ 11-126. http://dx.doi.org/10.1016/0167-7187(94)00453-9

Downie, J. (1958). The Competitive Process. Duckworth, London.

Dunne, P., \& A. Hughes. (1994). Age, size, growth and survival: UK companies in the 1980s. Journal of Industrial Economics, 42(2), 115-140. http://dx.doi.org/10.2307/2950485

Elston, J. A. (2002). An examination of the relationship between firm size, growth and liquidity in the Neuer Markt. Deutsche Bundesbank Discussion Paper Series 1, No. 15/02.

Evans, D. S. (1987). The Relationship between firm growth, size and age: estimates for 100 manufacturing industries. Journal of Industrial Economics, 35(4), 567-581. http://dx.doi.org/10.2307/2098588

Faulkender, M., \& M. A. Petersen. (2006). Does the source of capital affect capital structure? Review of Financial Studies, 19(1), 45-79. http://dx.doi.org/10.1093/rfs/hhj003

Florin, J. (2005). Is venture capital worth it? Effects on firm performance and founder returns. Journal of Business Venturing, 20(1), 113-135. http://dx.doi.org/10.1016/j.jbusvent.2003.12.006

Garcia-Teruel, P. J., \& P. Martinez-Solano. (2008). On the determinants of SME cash holdings: evidence from Spain. Journal of Business Finance and Accounting, 35(1-2), http://dx.doi.org/10.1111/j.1468-5957.2007.02022.x

Gibrat, R. (1931). Les Inegalites Economiques. Librairie du Receuil Sirey, Paris.

Gimeno, J., Folta, T. B., Cooper, A. C., \& C. Y. Woo. (1997). Survival of the fittest? Entrepreneurial human capital and the persistence of underperforming firms. Administrative Science Quarterly, 42(4), 750-783.

Hall, B. H. (1987). The relationship between firm size and firm growth in the U.S. manufacturing sector. Journal of Industrial Economics, 35(4), 583-606. http://dx.doi.org/10.2307/2098589

Hamelin, A., \& J. Trojman. (2007). Family ownership and growth: the case of French SMEs. Working Papers CEB No 07-024.RS.

Hardwick, P., \& M. Adams. (2002). Firm size and growth in the United Kingdom life insurance industry. Journal of Risk and Insurance, 69(4), 577-593. http://dx.doi.org/10.1111/1539-6975.00038

Harhoff, D., Stahl, K., \& M. Woywode. (1998). Legal form, growth and exist of West German firms - empirical results for manufacturing, construction, trade and service industries. Journal of Industrial Economics, 46(4), 453-488. http://dx.doi.org/10.1111/1467-6451.00083

Hart, P. E., \& S. J. Prais. (1956). The analysis of business concentration: a statistical approach. Journal of the Royal Statistical Society, 119(2), 150-191. http://dx.doi.org/10.2307/2342882 
Heshmati, A. (2001). On the growth of micro and small firms: evidence from Sweden. Small Business Economics, 17(3), 213-228. http://dx.doi.org/10.1023/A:1011886128912

Higson, C., Holly, S., \& P. Kattuman. (2002). The cross-sectional dynamics of the US business cycle: 1950-1999. Journal of Economic Dynamics and Control, 26(9-10), 1539-1555. http://dx.doi.org/10.1016/S0165-1889(01)00084-7

Higson, C., Holly, S., Kattuman, P., \& S. Platis. (2004). The business cycle, macroecomic shocks and the cross-section: the growth of UK quoted companies. Economica, 71(282), 299-318. http://dx.doi.org/10.1111/j.0013-0427.2004.00371.x

Hopenhayn, H. A. (1992). Entry, exit, and firm dynamics in long run equilibrium. Econometrica, 60(5), 1127-1150.

Hurst, E., \& B. W. Pugsley. (2011). What do small businesses so? Brookings Papers on Economic Activity, 2011(2) (Fall), 73-118. http://dx.doi.org/10.1353/eca.2011.0017

Huynh, K. P., \& R. J. Petrunia. (2010). Age effects, leverage and firm growth. Journal of Economic Dynamics and Control, 34(5), 1003-1013. http://dx.doi.org/10.1016/j.jedc.2010.01.007

Jensen, M. C. (1986). Agency costs of free cash flow, corporate finance, and Takeovers. American Economic Review, 76(2), 323-329.

Kumar, M. S. (1985). Growth, acquisition activity and firm size: evidence from the United Kingdom. Journal of Industrial Economics, 33(3), 327-338. http://dx.doi.org/10.2307/2098540

Lotti, F., Santarelli, E., \& M. Vivarelli. (2003). Does Gibrat's law hold among young, small firms? Journal of Evolutionary Economics, 13(3), 213-235. http://dx.doi.org/10.1007/s00191-003-0153-0

Mateev, M., \& Y. Anastasov. (2010). Determinants of small and medium sized fast growing enterprises in central and eastern Europe: a panel data analysis. Financial Theory and Practice, 34(3), 269-295.

McKelvie, A., \& J. Wiklund. (2010). Advancing firm growth research: a focus on growth mode instead of growth rate. Entrepreneurship Theory and Practice, 34(2), 261-288.

Moreno, A., \& J. Casillas. (2007, January). High-growth SMEs versus non-high-growth SMEs: a discriminant analysis. Entrepreneurship \& regional development, 19, 69-88. http://dx.doi.org/10.1080/08985620601002162

Muller, E. (2008). Benefits of control, capital structure and company growth. Applied Economics, 40(21), 2721-2734. http://dx.doi.org/10.1080/00036840600981622

Myers, S. C., \& N. S. Majluf. (1984). Corporate financing and investment decisions when firms have information that investors do not have. Journal of Financial Economics, 13(2), 187-221. http://dx.doi.org/10.1016/0304-405X(84)90023-0

Ozkan, A., \& N. Ozkan. (2004). Corporate cash holdings: an empirical investigation of UK companies. Journal of Banking and Finance, 28(9), 2103-2134. http://dx.doi.org/10.1016/j.jbankfin.2003.08.003

Pal, R., \& A. Ferrando. (2010). Financing constraints and firms' cash policy in the Euro area. European Journal of Finance, 16(2), 153-171. http://dx.doi.org/10.1080/13518470903075748

Penrose, E. (1959). The Theory of the Growth of the Firm. Oxford University Press, Oxford.

Rajan, R. G., \& L. Zingales. (1998). Financial dependence and growth. American Economic Review, 88(3), 559-586.

Roodman, D. (2009). How to do xtabond2: an introduction to difference and system GMM in Stata. Stata Journal, 9(1), 86-136.

Santarelli, E., Klomp, L., \& A. R. Thurik. (2006). Gibrat's law: an overview of the empirical literature. In Santarelli, E. (Ed.), Entrepreneurship, Growth, and Innovation: The Dynamics of Firms and Industries. Springer, New York. http://dx.doi.org/10.1007/0-387-32314-7_3

Schindler, M. (2009). The Italian labor market: recent trends, institutions and reform options. IMF Working Paper WP/09/47.

Sesil, J. C., Kroumova, M. K., Kruse, D. L., \& J. R. Blasi. (2007). Broad-based employee stock options in the U.S. company performance and characteristics. Management Review, The International Review of Management Studies, 18(1), 5-22.

Simon, H. A., \& C. P. Bonini. (1958). The size distribution of business firms. American Economic Review, 48(4), 607-617. 
Timmons, J. A. (1994). New venture creation: entrepreneurship for the 21st Century (4th ed.). Irwin Press, Burr Ridge, Chicago.

Vos, E., \& C. Roulston. (2008). SME owner involvement and business performance: financial security rather than growth. Small Enterprise Research, 16(1), 70-85. http://dx.doi.org/10.5172/ser.16.1.70

Vos, E., Yeh, A. J.-Y., Carter, S., \& S. Tagg. (2007). The happy story of small business financing. Journal of Banking and Finance, 31(9), 2648-2672. http://dx.doi.org/10.1016/j.jbankfin.2006.09.011

Wagenvoort, R. (2003). Are finance constraints hindering the growth of SMEs in Europe? EIB Papers, 7(2), 22-50.

Walker, E., \& A. Brown. (2004). What success factors are important to small business owners? International Small Business Journal, 22(6), 577-594. http://dx.doi.org/10.1177/0266242604047411

Wiklund, J., Davidsson, P., \& F. Delmar. (2003). What do they think and feel about growth? An expectancy-value approach to small business managers' attitudes toward growth. Entrepreneurship: Theory and Practice, 27(3), 247-269. http://dx.doi.org/10.1111/1540-8520.t01-1-00003

Witt, U. (2000). Changing cognitive frames - changing organizational forms: an entrepreneurial theory of organizational development. Industrial and Corporate Change, 9(4), 733-755. http://dx.doi.org/10.1093/icc/9.4.733

\section{Notes}

Note 1. A similar conclusion is drawn by Ozkan and Ozkan (2004) and Garcia-Teruel and Martinez-Solano (2008).

Note 2. We apply the definition of SMEs the Statistics of U.S. Business (SUSB) that defines SMEs as firms with less than 500 employees. We moreover require total sales to be below 50 million Euros per year.

Note 3. Santarelli et al. (2006) provide an overview on the empirical literature testing Gibtrat's law.

Note 4. See Coad (2007a) for an overview. Some empirical studies support a positive (e.g. Chesher, 1979; Bottazzi et al., 2001) while others report a negative serial correlation (e.g. Boeri and Cramer, 1992; Bottazzi et al., 2007). Even further studies have failed to find any autocorrelation in the data (e.g. Almus and Nerlinger, 2000; Lotti et al., 2003).

Note 5. To account for industry effects, we cluster industries by sectors. As the sectors show distinctive characteristics with regard to the structure of assets and financial needs, we employ two dummy variables: one for the more capital-intensive secondary sector (e.g. firms active in manufacturing and construction) and one for the more personnelintensive tertiary sector (e.g. firms active in wholesale as well as administrative and support services activities).

Note 6. This can be a consequence of the employment of the robust one-step GMM procedure.

Note 7. The employed definition deviates from the definition published by the European Commission (EC). The latter requires SMEs to have less than 250 employees instead of 500. The EC definition moreover requires total sales of below 50 million Euros or less than 43 million Euros total assets. Descriptive statistics (Table 2) however display that the mean and median number of employees of the SME samples is far below 250. Hence, the difference in the SME definitions should have only a negligible effect on our results.

Note 8. A full description of the industry distribution is available from the authors upon request.

Note 9. As all US firms in our sample are listed, we cannot analyse any effect from a listing for US firms.

Note 10. Especially in Italy material changes in labour law have taken place during the observation period (Schindler, 2009). 